\title{
The Expressive Dimension of Equal Protection
}

\author{
Deborah Hellman ${ }^{\dagger}$
}

There are two main schools of thought about the best way to understand what the Equal Protection Clause prohibits. First, there are those who say that the Clause prohibits laws that are enacted for the wrong sort of reasons, or to use the now canonical form of this view, with "invidious intent."1 Alternatively, there are those who argue that we ought to judge whether laws violate Equal Protection by looking at the impact of the laws and prohibit those that retrench social, and especially racial, inequalities. ${ }^{2}$ For quite some time, the first view-that intent is what matters in judging violations of Equal Protection-has been the official view, the view adopted by the Supreme Court, the view to beat. Many date the ascendancy of the intent-based understanding of Equal Protection to the Supreme Court's decision in the 1976 case Washington $v$. Davis, ${ }^{3}$ which rejected the claim that the disproportionate

$\dagger$ Associate Professor, University of Maryland School of Law; B.A., Dartmouth College; M.A., Columbia University; J.D., Harvard Law School. The bulk of the work on the Article was accomplished during a research leave supported by a National Endowment for the Humanities Fellowship for University Professors, which I thank for its generous support. Comments and criticism of the content of the Article were offered by the participants in the legal theory and faculty workshops at the University of Pennsylvania, University of Virginia, and University of San Diego. I also want to thank Matthew Adler, Richard Boldt, Andrew Koppelman, Richard Pildes, and Todd Rakoff for reading earlier versions of this Article and providing detailed comments and criticism. In addition, Bruce Ackerman and Kathleen Sullivan together with the other participants in the Stanford/Yale Junior Faculty Forum provided excellent commentary and helpful critique. Finally, I would like to thank Bryan Giblin and Rachel Wolf for excellent research assistance.

1. For the most influential defense of this process-based understanding of Equal Protection, see JOHN HART ELY, DEMOCRACY AND DISTRUST 136-45 (1980).

2. See, e.g., KENNETH L. KARST, BELONGING TO AMERICA: EQUAL CITIZENSHIP AND THE CONSTITUTION 13 (1989) (arguing that judges deciding cases under the Equal Protection Clause ought to ask whether their decisions will "perpetuate the exclusion of groups from equal citizenship"); ANDREW KOPPELMAN, ANTIDISCRIMINATION LAW AND SOCIAL EQUALITY 57-114 (1998).

3. 426 U.S. 229 (1976). 
impact of a facially neutral law was enough to demonstrate a prima facie violation of the Equal Protection Clause. ${ }^{4}$ During this same period, the second view-that a law's effect is what matters in judging what constitutes unequal protection-has been the major alternative view offered by the Court's most vocal critics. Into this largely bifurcated constitutional field, this Article offers a third way.

This Article argues that we ought to judge whether state action violates Equal Protection not by looking at the intent of those who enacted laws nor by looking at the effect a law has in the domain in which it operates. Rather, we ought to judge whether laws violate Equal Protection by looking at the meaning or expressive content of the law or policy at issue. This theory can be briefly stated: state action violates Equal Protection if its meaning conflicts with the government's obligation to treat each person with equal concern. This Article advances the claim that the constitutional wrong inheres in what the law expresses. In what follows, I will defend this theory.

This middle course is not entirely new-things rarely are. Rather, it picks up a forgotten strand of Equal Protection

4. See, e.g., Daniel R. Ortiz, The Myth of Intent in Equal Protection, 41 STAN. L. REV. 1105, 1105 (1989) (describing the reaction of commentators to Washington v. Davis in this way: "All agree, however, that current doctrine makes intent the key to equal protection."). In Washington, the Supreme Court rejected the claim that the fact that a greater percentage of black applicants than white applicants failed the standardized test used by the District of Columbia in screening police recruits was sufficient to sustain a prima facie violation of the Fifth Amendment's Due Process Clause. 426 U.S. at 238-39. In explaining the Court's holding, Justice White characterized the requirement of invidious intent as central to the constitutional claim of wrongful discrimination: "[O]ur cases have not embraced the proposition that a law or other official act, without regard to whether it reflects a racially discriminatory purpose, is unconstitutional solely because it has a racially disproportionate impact." Id. at 239. Interestingly, the opinion does not clearly define how invidious intent is conceived. In particular, the text of the opinion could be read to support either the view that the actual subjective intent of legislators is what matters or the view that it is intent, understood objectively, that is important. For example, the Court explains that "an invidious discriminatory purpose may often be inferred from the totality of the relevant facts, including the fact, if it is true, that the law bears more heavily on one race than another." Id. at 242. For a discussion of the relationship between subjective intent, objective intent, and expressive character, see infra notes 122-148 and accompanying text. Justice Stevens, in his concurring opinion, notes precisely this ambiguity. See Washington, 426 U.S. at 254 (Stevens, J., concurring) (explaining that "the line between discriminatory purpose and discriminatory impact is not nearly as bright, and perhaps not quite as critical, as the reader of the Court's opinion might assume"). 
jurisprudence, one articulated forcefully by Charles Black ${ }^{5}$ in his insightful 1960 defense $^{6}$ of Brown v. Board of Education, ${ }^{7}$ and continued intermittently in the years since. ${ }^{8}$ Black begins his analysis of Brown with the "plain fact about the society of the United States-the fact that the social meaning of segregation is the putting of the Negro in a position of walledoff inferiority." "Social meaning" in Black's terms is what I term here the "expressive content" or "expressive character" of the law or policy. ${ }^{10}$ Each of these terms calls attention to what a law expresses (in this case about the worth of black children) or what meaning it conveys. For Black, as for me, it is this social meaning that is the real meaning of unequal protection and the source of the constitutional violation.

Interestingly, the Court's continued attachment to improper intent as the basis of the Equal Protection violation has been consistently and effectively criticized over the years. Briefly, the intent doctrine has been criticized as incoherent because determining the intent of a group like a legislative body is both philosophically as well as practically problematic. ${ }^{11}$

5. Charles Black is not the first to articulate that it is the expressive character of state action that is most important to assessing its constitutional permissibility. As early as 1879 in Strauder $v$. West Virginia, the Supreme Court recognized that a law which forbids blacks from jury service violates Equal Protection because it is "practically a brand upon them." 100 U.S. 303, 308 (1879).

6. See Charles L. Black, Jr., The Lawfulness of the Segregation Decisions, 69 YALE L.J. 421 (1960).

7. 347 U.S. 483 (1954).

8. See infra Part II.E.

9. Black, supra note 6 , at 427 .

10. At the suggestion of Richard Pildes, I have largely abandoned use of the term "social meaning" in favor of the "expressive dimension" or "expressive character" of a law or policy. While I continue to understand all three terms as synonyms, Pildes has pointed out that "social meaning" is understood by some readers as calling attention to the effects of laws rather than to their expressive character. E-mail from Richard Pildes, Professor, University of Michigan Law School, to Deborah Hellman, Associate Professor, University of Maryland School of Law. This confusion is understandable because Lawrence Lessig has used the term "social meaning" in an article focusing on how laws play a role in the creation of social norms. See Lawrence Lessig, The Regulation of Social Meaning, 62 UNIV. OF CHI. L. REV. 943, 951 (1995). This Article uses the terms "meaning" (by itself), "expressive character," or "expressive dimension" to indicate what a law or policy expresses.

11. E.g., Sheila Foster, Intent and Incoherence, 72 TUL. L. REV. 1065, 1121-43 (1998) (criticizing the Court's approach to determining intent as incoherent); David A. Strauss, Discriminatory Intent and the Taming of Brown, 56 U. CHI. L. REV. 935, 938 (1989) (criticizing throughout "the potentially incoherent nature of the discriminatory intent standard"). But see 
Second, even at the individual level, it is often difficult to know or assess the precise reasons for an individual's action. Unconscious or subtle motives may guide us without our recognition of their influence. ${ }^{12}$ Third, moral responsibility for actions extends beyond those actions one specifically intends. ${ }^{13}$ Surely the failure to take the interests of a particular group into account-indifference rather than animus-is to deny those affected the law's equal protection. Fourth and finally, while intent is relevant to assessing the moral culpability of legislative actors, courts ought to interpret the Equal Protection Clause to police how people are treated by their government. We ought to be interested in the permissibility of laws, not in the purity of legislative motives. ${ }^{14}$

Yet, this doctrinal implementation of the Clause has persisted. In large part, this is probably because the alternative, an effect-based conception, is perceived to be too radical. As David Strauss quite aptly explains, the intent doctrine "tamed" the transformative possibilities of Brown. ${ }^{15}$ But it is not just conservatism that accounts for the rejection of

Elizabeth S. Anderson \& Richard H. Pildes, Expressive Theories of Law: A General Restatement, 148 U. PA. L. REV. 1503, 1514-27 (2000), for a powerful defense of the conception of group mental state.

12. See Barbara J. Flagg, "Was Blind, But Now I See": White Race Consciousness and the Requirement of Discriminatory Intent, $91 \mathrm{MrCH}$. L. REV. 953, 980 (1993) (arguing that the intent standard ignores the presence of white race consciousness); Charles R. Lawrence III, The Id, The Ego, and Equal Protection: Reckoning with Unconscious Racism, 39 STAN. L. REV. 317, 322 (1987) (arguing that the intent standard ignores the "unconscious racism" that is often the cause of wrongful discrimination).

13. This concept is well-rooted in tort and criminal law. See, e.g., DAN B. DOBBS ET AL., PROSSER AND KEETON ON THE LAW OF TORTS $§ 28$, at 161 (5th ed. 1988) ("Intentional injuries, whether direct or indirect, began to be grouped as a distinct field of liability, and negligence remained as the main basis for unintended torts. Negligence thus developed into the dominant cause of action for accidental injury in this nation today.") (footnotes omitted); ROLLIN M. PERKINS \& RONALD N. BOYCE, CRIMINAL LAW 858 (3d ed. 1982) (explaining that "[t]he fact that malice does not require an actual intent to cause the actus reus has been well understood").

14. See Todd Rakoff, Washington v. Davis and the Objective Theory of Contracts, 29 HARV. C.R.-C.L. L. REV. 63, 76 (1994) (arguing that "[w]e are not really that interested in whether our officials have good or bad soulscertainly not so interested as to make that question our touchstone for the 'equal protection of the laws"').

15. Strauss, supra note 11, at 939 (arguing that the Court adopted a discriminatory intent standard despite its obvious shortcomings because of its concern that alternatives that focused on the effect of state action-like the stigma and anti-subordination conceptions of the Equal Protection-would be "far too threatening to established institutions"). 
effect as the gravamen of Equal Protection. Equal Protection does speak to issues of social justice, but it is best understood as a specific protection. While it is difficult to specify precisely what Equal Protection protects-indeed, that is the project of this Article as well as a surfeit of others-we weaken its power and dilute its special appeal to deep and shared moral intuitions if we interpret it as a general guarantee of distributional fairness. For example, the current flat tax proposal would violate an anti-subordination conception of Equal Protection if it turned out that the law worked to entrench racial inequality. While a flat tax may be inimical to the demands of justice in that justice may well require redistribution, it seems a stretch to claim that the flat tax denies people the Equal Protection of the laws. To read the Clause as equivalent to a general requirement of social justice is to sap the Equal Protection Clause of its unique potency.

But this overreaching of effect-based views ${ }^{16}$ ought not force us to retreat to the inadequacies of the intent-based conception. Instead, I propose a third way, a middle course between the poles of intent and effect. I arrive at the view that the meaning of governmental actions ought to determine whether laws violate Equal Protection by beginning with two paradigm cases: Brown v. Board of Education 17 and Plessy $v$. Ferguson. ${ }^{18}$ The legal community is far more certain that the result in Brown was right and the result in Plessy wrong than it is that any particular theory of Equal Protection is correct. Therefore, it makes sense to start with these guideposts, to use them to help us understand when and on what grounds laws violate Equal Protection.

Part I begins with Brown as the lodestar and Plessy as its antipode to unravel what makes wrongful discrimination wrong. Using the insights these paradigm cases provide, Part II articulates a new theory of when discrimination violates Equal Protection, a third way between the intent and effectbased views. The central claim is that it is the expressive character of state action that determines whether a law or

16. Of course not everyone thinks these effect-based conceptions are in fact over-reaching. Two prominent, well-conceived examples are Kenneth Karst and Andrew Koppelman. See Kenneth L. Karst, The Supreme Court, 1976 Term-Foreword: Equal Citizenship Under the Fourteenth Amendment, 91 HARV. L. REV. 1 (1976); sources cited supra note 2.

17. 347 U.S. 483 (1954).

18. 163 U.S. 537 (1896). 
policy violates Equal Protection. In the context of laying out this view, Part II explains which meanings the theory proscribes and how this meaning is determined. In addition, Part II demonstrates that this type of inquiry will not be unfamiliar as courts already look at the expressive dimension of state action when applying other constitutional protections. Finally, Part II anticipates objections to the theory presented, looking particularly at such problems as the elusiveness of meaning and the problem of standing.

Part III of this Article then applies this theory in three specific contexts: veterans' preferences, Colorado's Amendment 2 that was struck down in Romer $v$. Evans, ${ }^{19}$ and restrictions on non-citizens. The goal of this Part is first to give the reader a clearer sense of the theory by watching it operate in practice. Second, Part III will demonstrate how an expressive theory of Equal Protection requires courts to ask different questions than does current doctrine. As one might expect, because the new theory makes different issues salient, at times it yields results that conflict with previously decided cases.

\section{PARADIGM CASES}

\section{A. METHOD}

We test any plausible theory of when discrimination violates Equal Protection with reference to our strongest intuitions about which cases, decided as well as hypothetical, are clearly right. In other words, this Article adopts a method of inquiry akin to what John Rawls has termed "reflective equilibrium." 20 As a philosophical method, reflective equilibrium gives as much weight to judgments about particular instances as to abstract theory. Rawls, whose goal is to provide an account of the basic political framework for a just society, tests the evolving contenders for those principles against both the society's "considered judgments" 21 about fairness and justice in particular cases and in reference to the abstract principles developed by his approach. Resolution requires tinkering at both the level of the particular judgment and at the level of theory. In practice, this requires that one must be equally ready to reject a theory that leads to a result

19. 517 U.S. 620 (1996).

20. JOHN RAWLS, A THEORY OF JUSTICE 46-53 (1972).

21. Id. at 47 . 
that clashes with a considered judgment as one is to reject a particular result allegedly proved false by the theory. The inquirer moves back and forth between the level of abstract theory and the level of considered judgments until the two are brought into a "reflective equilibrium"-a sort of balance point at which additional tinkering at either end would no longer produce increased consistency nor increased confidence in the result.

As Nelson Goodman has argued, this method may indeed be the only way to justify anything. Goodman explains,

[t]he point is that rules and particular inferences alike are justified by being brought into agreement with each other. A rule is amended if it yields an inference we are unwilling to accept; an inference is rejected if it violates a rule we are unwilling to amend. The process of justification is the delicate one of making mutual adjustments between rules and accepted inferences; and in the agreement achieved lies the only justification needed for either. ${ }^{22}$

What this means for the kind of moral/constitutional theory that this Article presents is that if a theory of wrongful discrimination clashes with our considered judgments about particular cases, then we must take a close look at both that theory and that particular case. Judgments about particular cases that are thoughtfully considered exert strong pressure on those theories that fail to account for them.

\section{B. A MEDIATING PRINCIPLE}

Section 1 of the Fourteenth Amendment provides:

No State shall make or enforce any law which shall abridge the privileges or immunities of citizens of the United States; nor shall any State deprive any person of life, liberty, or property, without due process of law; nor deny to any person within its jurisdiction the equal protection of the laws. ${ }^{23}$

Clearly this clause requires elaboration. In the words of Owen Fiss, it requires a "mediating principle."24 By this, Fiss means that one needs a way to translate the prohibition on unequal protection of the laws into a principle that can be more readily understood and applied to cases before us. A widely accepted mediating principle is needed to avoid prejudging the inquiry into how courts ought to analyze when and whether legal classifications violate equal protection. In the language of

22. NELSON GOODMAN, FACT, FICTION, AND FORECAST 64 (4th ed. 1983).

23. U.S. CONST. amend. XIV, § 1 .

24. Owen M. Fiss, Groups and the Equal Protection Clause, in EQUALITY AND PREFERENTIAL TREATMENT 85-88 (Marshall Cohen et al. eds., 1977). 
moral philosophy, it must be a "thin" conception of equal protection, one that doesn't import controversial conceptions of what that clause requires through the back door. Ronald Dworkin describes the commitment underlying the Clause in this way: "From the standpoint of politics, the interests of the members of the community matter, and matter equally."25 This idea, that we must matter equally to our government, is "too fundamental," according to Dworkin, to be argued for itself: "It seems unlikely that it can be derived from any more general and basic principle of political morality that is more widely accepted." 26 If Dworkin is right, as I believe he is, then the principle of equal concern provides a good starting place. We start, therefore, with the claim that Equal Protection requires the equal concern of government for all. ${ }^{27}$

\section{BROWN V. BOARD OF EDUCATION}

If we take the holding of Brown $v$. Board of Education as a provisionally fixed point in our constitutional firmament, we must ask what makes it so. Why-for what reasons-was de jure racial segregation of the public schools in Kansas at odds with Equal Protection?

The Court in Brown, while not articulating a clear theory, seems to rest its finding of violation on three grounds: the meaning of segregation; the harm to African-American school children caused by this meaning; and the extreme importance of education to the individual and to the society. ${ }^{28}$ Notably, the Supreme Court begins its analysis with the claim that segregation expresses denigration of African-Americans. Approvingly quoting the lower court opinion, the Supreme Court acknowledges that segregation is "usually interpreted as (1983)

25. Ronald Dworkin, In Defense of Equality, 1 Soc. PHIL. \& POL'Y 24, 24

26. Id. at 31. Jeremy Waldron calls our attention to the fact that the commitment to the equal worth of all human beings that underlies moral argumentation needs elaboration and clarification. In an essay, he seeks to understand to what we in fact commit ourselves in taking this position as the basis for moral claims. See Jeremy Waldron, Basic Equality: An Undifferentiated Human Range, in TwO ESSAYS ON BASIC EQUALITY (1999), at http://www.law.nyu.edu/clppt/orginalpapers/waldron.doc (last visited Sept. 9, 2000).

27. Dworkin employs this thesis in working out how Hercules would analyze cases of racial discrimination. See RONALD DWORKIN, LAW'S EMPIRE 381-99 (1986).

28. See Brown v. Bd. of Educ., 347 U.S. 483 (1954). 
denoting the inferiority of the negro group."'29 Next, the Court claims that this meaning matters because it will harm the African-American school children affected. In the Court's most famous words: "To separate [African-American school children] ... from others of similar age and qualifications solely because of their race generates a feeling of inferiority as to their status in the community that may affect their hearts and minds in a way unlikely ever to be undone." 30 And finally, the Court dwells most, devoting a whole paragraph in this notably short opinion, on the importance of education to both the child and the society. The Court observes that "it is doubtful that any child may reasonably be expected to succeed in life if he is denied the opportunity of an education"31 (importance to the child) and that education "is the very foundation of good citizenship"32 (importance to the state).

By stressing the importance of education and the effect that sending a message of inferiority has on that education, the Court essentially makes the case that although the services and supplies of the segregated schools are not unequal, the education is. The African-American children who imbibe this message will not get as good an education as the white children because their feelings of inferiority caused by segregation will sabotage their sense of their own potential and thus negatively affect their ability to learn. By weaving together these two themes, the importance of education and the meaning of segregation to African-American children, the Court arrives at a very concrete harm to the plaintiff students: unequal education.

Interestingly, the Court makes a clearly false claim that is in fact belied by its own analysis that "[s]eparate educational facilities are inherently unequal." 33 The opinion's authors probably used the term "inherently" both for emphasis and to forestall any attempts to show that particular children in particular schools were not affected by the stigma. If the inequality is inherent in segregated education, there will be no need to litigate the significance of small differences between

29. Id. at 494 (quoting Brown v. Bd. of Educ., 98 F. Supp. 797 (D. Kan. 1951)).

30. Id.

31. Id. at 493 .

32. Id.

33. Id. at 495 . 
different school districts. ${ }^{34}$ But of course the reasons that ground the Court's opinion-the importance of education in our society and the meaning of segregating by race in our cultureshow that racial segregation is contingently unequal. It violates Equal Protection because of the particular meaning of that practice in our society.

While the Court is surely right about the ways that segregation concretely harms African-American school children, this harm is not necessary to the Equal Protection violation. The violation inheres in the fact that the expressive character of the state's action conflicts with the commitment to equal concern that underlies the Equal Protection principle. The state may not adopt policies that express a message of unequal worth; this is what the Equal Protection Clause prohibits. And it is a prohibition that operates without regard to whether the state action causes concrete harm to identifiable people.

An example will support this claim. Suppose Kansas had funded and operated racially segregated day care centers for infants. Surely this practice would also violate Equal Protection. And yet, it is unlikely that the babies in the centers would be psychologically affected. Since they are so young, they are unlikely to know or understand the racial segregation being practiced. Therefore, psychological harm to particular individuals affected must not be necessary for such a violation to occur. For readers who find that example unconvincing because they think even babies are aware enough of their social environment to take in small cues of stigma, one need only modify the hypothetical. Perhaps the state segregates longterm care facilities for patients in a persistent vegetative state. If this practice would also violate Equal Protection, then psychological harm or stigma cannot be a necessary component of an Equal Protection violation.

Although these examples may tax the reader's tolerance for academic style hypotheticals, they have a purpose. If our intuitions remain strong that racial segregation of day care centers and long-term care facilities for the incompetent also violates Equal Protection, then we know that it cannot be the

34. In cases following Brown v. Board of Education, courts treated de jure segregation as unconstitutional without discussion. E.g., Sch. Bd. v. Allen, 240 F.2d 59, 60-62 (4th Cir. 1956); Jackson v. Rawdon, 235 F.2d 93, 96 (5th Cir. 1956); Clemons v. Bd. of Educ., 228 F.2d 853, 856 (6th Cir. 1956); Romero v. Weakley, 226 F.2d 399, 400-01 (9th Cir. 1955). 
effect on the "hearts and minds" of the school children in Brown that grounds the Equal Protection violation there. If not, we need an alternative account.

As noted earlier, there are three themes in Brown on which the decision rests: the meaning of segregation, the harm to African-American children, and the importance of education. We have just determined that the second is not necessary. As for the third, while education certainly is important for equal opportunity, it is unlikely to be the source of the Equal Protection violation, effectively making education a fundamental right, ${ }^{35}$ because this account would leave other forms of state sponsored racial segregation untouched. This leaves us with the meaning of segregation as the root of the evil.

Of course, since we are trying to find the right account of when and why laws violate Equal Protection, we are not limited to the reasons offered in Brown. We study Brown for guidance, not as authority, so its reasons are only as good as they turn out on inspection to be. Brown's holding is a provisionally fixed point which can be used as a starting place in evaluating theories of Equal Protection.

\section{PLESSY V. FERGUSON}

A second case to consider is Brown's antipode: Plessy $v$. Ferguson. ${ }^{36}$ Plessy wrongly held that a Louisiana law that required separate seating for the white and "colored" passengers of an intrastate railroad company did not violate Equal Protection. ${ }^{37}$ I take this considered judgment to be another provisionally fixed point. But where exactly did Plessy go wrong? The most striking claim in Justice Brown's opinion for the Court is notorious. Brown claims:

We consider the underlying fallacy of the plaintiffs argument to consist in the assumption that the enforced separation of the two races stamps the colored race with a badge of inferiority. If this be so, it is not by reason of anything found in the act, but solely because the colored race chooses to put that construction upon it..$^{38}$

35. But see Plyler v. Doe, 457 U.S. 202, 230 (1982) (holding that the denial of a free public education to illegal aliens violates Equal Protection under rational basis review). Plyler demonstrates that the Court can subject classifications that affect education to extra scrutiny without finding that education is in fact a fundamental right.

36. 163 U.S. 537 (1896).

37. Id. at 550-51.

38. Id. at 551. 
It is hard to take this claim seriously or to believe that Justice Brown is honest when he writes it. But putting aside his sincerity and facility (or lack thereof) in reading cultural symbols, one thing is certain; this claim is false. AfricanAmericans in 1895 could no more change the meaning of segregation in Louisiana by simply attributing a different construction to it than a small group can unilaterally change the meaning of an English word. ${ }^{39}$ Rather, as Justice Harlan's dissent explains, "as all will admit, ... the real meaning of ... [the legislation]" is "that colored citizens are so inferior and degraded that they cannot be allowed to sit in public coaches occupied by white citizens." 40

But of course this is all fairly obvious. It is obvious that Justice Brown got the meaning of segregated rail cars in 1895 Louisiana wrong. And it is also obvious that the meaning of the practice of segregation at that time was culturally produced and consequently not something from which an individual or minority group could simply opt out. The group can try to change the meaning of the practice, or it can try to change the practice, but it cannot simply reject the meaning unilaterally as Justice Brown suggests. ${ }^{41}$

So the insight we derive from looking closely at Plessy is that Justice Brown's opinion is wrong because it rests on the false claim that the meaning of segregated rail cars in 1895

39. Of course the meaning of language does change over time and often because small groups of people adopt a difference usage for a term. But it does so very gradually. When the pace is relatively quick, this is often because of a concerted social movement to consciously affect the meaning of a term. Interestingly, civil rights movements often try to change language first as a means to change status. "African-American" replaces "black" which replaced "colored" as the social status of the group advanced. "He and she" replaces the allegedly gender-neutral "he" as women gain power. Changing the social meaning of a practice rather than of one word or term is probably even more difficult. Gay pride marches are a good example of an attempt to do just this. Clearly it is not an easy task.

40. Plessy, 163 U.S. at 560 (Harlan, J., dissenting) (emphasis added).

41. Lawrence Lessig uses the term "social meaning" in an article addressing the ways in which governments unavoidably participate in the creation of that meaning in order to emphasize that the meanings of practices are culturally dependent. Lessig, supra note 10. As Lessig notes, there is nothing deep or controversial about the term "social meaning" as opposed to simply "meaning." Id. at 951-52. Rather he uses it "not to distinguish social meaning from individual meaning (whatever that would be), or meaning more generally, but rather to emphasize its contingency on a particular society or group or community within which social meanings occur." Id. 
was not in conflict with the equal worth of African-Americans. ${ }^{42}$ Justice Harlan's opinion is right because he correctly reads the cultural significance of that law. ${ }^{43}$ From Plessy and Brown, a theory emerges: whether discrimination violates Equal Protection depends on the expressive content of the law or policy.

\section{THE EXPRESSIVE CONCEPTION OF EQUAL PROTECTION}

\section{A. THE Clatm}

A legal classification violates Equal Protection if the meaning of the law or practice in our society at the time conflicts with the government's obligation to treat us with equal concern. In other words, in order to treat people with equal concern, the government may not express, in words or deeds, that it values some of us more than others. Therefore, the segregation at issue in Brown violated the Clause because the best understanding of the practice of segregation was as an expression of the view that African-Americans are not worthy of being educated with whites. What both Brown and Plessy illustrate is that to treat people equally, the state must express that value. Just as respecting someone requires acting respectfully, so too equal concern requires expressing equal concern.

At this point, the critic might object that without a concrete harm to point to, this understanding of the constitutional wrong is too open-ended. Just as negligence in the air is not actionable because it does not cause a harm, so too, one could argue, expressive violation loses its bearing if it is not grounded in psychological harm. ${ }^{44}$ This objection, while superficially powerful, turns out to beg the question whether some moral or constitutional commands restrict expressive action.

The law makes negligent conduct actionable because we care about its consequences. Because people are hurt by the negligent conduct of others, they are entitled to recover against

42. 163 U.S. at 551.

43. See id. at 560 (Harlan, J., dissenting).

44. This objection was suggested to me by Todd Rakoff. E-mail from Todd Rakoff, Professor, Harvard Law School, to Deborah Hellman, Associate Professor, University of Maryland School of Law. 
the negligent actor. In other words, the legal restraint is supported by consequentialist reasons. As a result, it makes sense to limit recovery to instances of negligence that have caused harm. By contrast, the theory of Equal Protection advanced here argues that Equal Protection is essentially concerned with expressive action. This claim explicitly denies that the wrong is rooted in consequentialist concerns. By its nature, an expressive harm is always "in the air." To require harm or psychological injury would be to convert the theory into something quite different.

Moreover, the fact that stigma or psychological injury is not a necessary component of an Equal Protection violation is a virtue of this theory. Given the diversity of our nation, it would be good to encourage a civic culture of both tolerance and toughness. We are likely to offend each other inadvertently quite often. Therefore, while names certainly can hurt, we continue to teach children the "sticks and stones" maxim in order to inculcate in them a sense of self that is difficult to hurt with words. Thick skin is a virtue in a diverse society. In saying this, I surely do not mean that state action that expresses unequal regard ought not be treated seriously. To the contrary, this Article argues that it is a serious violation of Equal Protection. It is a strength of my theory that people can challenge state action without needing to assert that they have been stigmatized. Some cultural critics have attacked what they see as the growth of a culture of victimhood.45 My theory ensures that governmental action does not denigrate any person or group, while simultaneously not discouraging the thick skin that ought to be treated as a civic virtue.

\section{B. WHICH MEANINGS ARE PROSCRIBED?}

In order to complete the theory, this Article must articulate criteria for determining which meanings are prohibited. In the above two examples (Plessy and Brown) this did not seem necessary because the meaning of segregation so clearly conflicts with any plausible understanding of what Equal Protection protects. But not all cases will be so unambiguous. It is in the unclear cases that the mediating principle of the Equal Protection Clause begins to do some work.

45. See, e.g., ROBERT HUGHES, THE CULTURE OF COMPLAINT (1993). 
The antimiscegenation statute at issue in Loving $v$. Virginia ${ }^{46}$ provides a clear example of how the principle of equal concern prohibits some expressive content. In Loving, the Court correctly interpreted the meaning of the antimiscegenation law as "obviously an endorsement of the doctrine of White Supremacy." 47 The fact that the law at issue forbade whites to marry people of any other race but allowed the intermarriage of other non-white groups (AfricanAmericans and Asian-Americans for example) made this especially clear. ${ }^{48}$ This meaning - that the white race must be protected from intermingling with other races because it is a superior race-conflicts with the principle of equal concern and respect. The statute expressed that whites are superior and that the purity of the white race and no other is of supreme importance to the state. The principle of equal concern forbids the state from adopting or endorsing this view. Accordingly, the antimiscegenation statute violated Equal Protection.

Single sex bathrooms in public buildings present a similarly easy case. Although this classification discriminates on the basis of sex, single-sex bathrooms do not violate Equal Protection because their meaning is innocuous. While there is expressive content to this practice, perhaps that certain bodily functions ought to be kept private from the opposite sex, this meaning does not imply less regard for one sex or the other. ${ }^{49}$ Therefore, this segregation does not violate Equal Protection. There are surely many other cases of legal classifications which are obviously either permissible due to harmless expressive content or impermissible due to a noxious meaning.

46. 388 U.S. 1 (1967).

47. Id. at 7.

48. Id. at 11-12 n.11. The scope of this particular antimiscegenation statute made its noxious meaning exceptionally obvious, but if Virginia had forbidden any marriages between men and women of different races, that too would have violated Equal Protection because the meaning of such a law in Virginia at that time would also have been one of racial superiority of whites over non-white races. In other words, facial neutrality doesn't ensure that a law's meaning will be unproblematic. Cultural practices contribute to the objective meaning of laws.

49. On reflection, the social meaning of this practice does raise some equal protection concerns, but not of sex discrimination. The social meaning of this practice is surely that heterosexuality is the norm. Whether this social meaning merely points to the relative frequency of each sexual orientation or instead expresses the view that heterosexuality is better or preferred is an interpretive question that requires further thought. 
The meaning of other laws or practices may well be more controversial. For example, a few years ago, the Fifth Circuit struck down an admissions preference for African-Americans and Mexican-Americans at the University of Texas Law School in Hopwood v. Texas. ${ }^{50}$ The court's opinion rejected educational diversity as a compelling state interest that would justify racebased admission preferences and found that the University of Texas Law School had not shown that the present effects of past discrimination by the school warranted the use of racebased admissions criteria. ${ }^{51}$ Under current Equal Protection doctrine, the use of a racial classification to select for black applicants directly (what I termed, in a previous article, "nonproxy discrimination"52) is impermissible. Racial classifications are only permitted, and infrequently even on these grounds, when race is used as a proxy for past victims of discrimination in a particular labor market ${ }^{53}$ or as a proxy for diversity of viewpoint or experience in the higher education context. ${ }^{54}$ Proponents of affirmative action, therefore, style their defenses to fit the available doctrinal categories. In my view, however, law schools generally practice affirmative action in order to

50. 78 F.3d 932 (5th Cir. 1996).

51. Id. at $944,955$.

52. Deborah Hellman, Two Types of Discrimination: The Familiar and the Forgotten, 86 CAL. L. REV. 315 (1998). In that article I draw a distinction between "proxy" and "non-proxy" discrimination. In proxy discrimination, a law or policy picks out people with one trait in order to reach people with a different correlated trait. Id. at 317-18. In non-proxy discrimination, the law picks out people with a particular trait in order to reach precisely those people. Id. at 318-19. For example, if a law firm were to prefer men to women as associates because the firm partners believe that women are generally less aggressive than men, this is proxy discrimination. Sex is used as a proxy for aggressiveness. In contrast, single-sex education is an instance of non-proxy discrimination. The school admits only women in order to have a class of women only. The article goes on to argue that current Equal Protection doctrine is geared to handle instance of proxy discrimination only. As a result, when faced with a case of non-proxy discrimination, courts are doctrinally illequipped. Id. at 328-38.

53. See, e.g., Richmond v. J.A. Croson Co., 488 U.S. 469, 505-09 (1989) (finding that a set-aside program for minority contractors was not narrowly tailored to remedy past discrimination because no such discrimination had existed in the Richmond construction industry); Wygant v. Jackson Bd. of Educ., 476 U.S. 267, 277 (1986) (plurality opinion) (invalidating a school policy awarding unbalanced protection against layoffs to minority teachers on the grounds that there was not "sufficient evidence to justify the conclusion that there had been prior discrimination").

54. See, e.g., Regents of the Univ. of Cal. v. Bakke, 438 U.S. 265, 316-18 (1978) (discussing with approval Harvard College's use of race as a plus factor in admissions). 
have more minority students, period. Race is not really used as a proxy for viewpoint or experience.

But ought it be permitted? The theory articulated in this Article instructs that discrimination is impermissible when the expressive character of the law or policy conflicts with the principle of equal concern. While the meaning of affirmative action may be controversial, that meaning is probably not at odds with this principle. Affirmative action expresses inclusion, not exclusion. While individual white applicants who would be admitted under a race-blind system are in fact excluded (in other words, they do suffer concrete harm), the best understanding of the practice in our culture today is not that white students are not welcome or worthy of admission at Texas's law school. This conclusion does not imply that affirmative action is necessarily wise policy; it may well have harmful consequences that must be weighed against its beneficial effects. But it does mean that affirmative action does not raise an Equal Protection problem.

According to the theory advanced in this Article, expressive state action only violates Equal Protection if its content conflicts with the principle of equal concern. For this reason, affirmative action is unproblematic. Other scholars take a broader view of what expressive content is proscribed. For example, Richard Pildes and Richard Niemi claim, in the voting rights context, that the state may not express that race-based considerations dominate decision-making. 55 They argue that the constitutional infirmity in Shaw $v$. Reno ${ }^{56}$ lay in the fact that drawing an odd-shaped congressional district in order to create a majority-minority district impermissibly expressed that race was the dominant factor in the drawing of district lines. ${ }^{57}$ This is a problem, in their view, because state actions are required to express a sort of value pluralism: "In resisting

55. Richard Pildes \& Richard Niemi, Expressive Harms, "Bizarre Districts," and Voting Rights: Evaluating Election-District Appearances After Shaw v. Reno, 92 MICH. L. REV. 483, 500-01 (1993).

56. 509 U.S. 630 (1993); see infra Part II.D.

57. Pildes and Niemi argue:

For the Court, what distinguishes "bizarre" race-conscious districts is the signal they send out that, to government officials, race has become paramount and dwarfed all other, traditionally relevant criteria. This view is the foundation of the qualitative distinction central to Shaw: at a certain point, the use of race can amount to value reductionism that creates the social impression that one legitimate value has come to dominate all others.

Pildes \& Niemi, supra note 55, at 501. 
the use of race in this specific way, Shaw requires that redistricting continue to be understood-and, perhaps more importantly, perceived-as implicating multiple values. Public officials must maintain this commitment to value pluralism, even when they legitimately and intentionally take race into account."58 But why is the endorsement of value pluralism a constitutional necessity? Expressing that race is dominant or decisive may lead to a sort of reification of racial categories. This is a powerful argument and an important concern, but it is a concern for policy-makers only. The Pildes and Niemi account is missing an explanation of why or how the Equal Protection Clause requires value pluralism.

This Article defends the view that state action may not express unequal regard for persons because the Equal Protection Clause requires that the government treat each of us with equal concern. It is the normative content of Equal Protection itself that sets the boundaries on what state actions may not express. In other words, I agree with Pildes and Niemi that the expressive character of governmental action matters, but I contend that the Equal Protection Clause prohibits only those meanings that conflict with the principle of equal concern. ${ }^{59}$

\section{How IS THE EXPRESSIVE CHARACTER OF LAW DETERMINED?}

People are likely to disagree about what particular laws and policies express. How, then, should judges determine the meaning of state action? The judge must decide as best she can, while listening closely to the views of others. Insightful commentary by the philosopher Georgia Warnke on the

58. Id.

59. Pildes and Niemi argue that the reason North Carolina's congressional district violates Equal Protection is analogous to the reason that quotas but not preferences violate Equal Protection in the education context. Id. at 503. Presumably, preferences are permissible where quotas are not because while the concrete effect on applicants may be similar, the message conveyed is not. As I understand this view, quotas express that race is the decisive factor; preferences express that race is one factor among many. See $i d$. But what is constitutionally problematic about expressing that race is decisive for a set number of applicants? Quotas express that because race continues to matter in our society, a state must ensure that it educates members of each racial group. While this approach to the continued relevance of race in society may not be wise (I make no claim either way), this expressive content does not conflict with the government's obligation to treat each of us with equal concern. 
political theory of John Rawls ${ }^{60}$ demonstrates why this answer is the most we can hope for. In Political Liberalism ${ }^{61}$ Rawls explores how people with different values and beliefs can live together in a political system that is fair given their many differences. He is looking for a conception of justice that can be endorsed from within all reasonable substantive views of what is good. In his words, "political liberalism looks for a political conception of justice that we hope can gain the support of an overlapping consensus of reasonable religious, philosophical, and moral doctrines in a society regulated by it." 62

Both Rawls's description of his project and his theory of political liberalism take seriously society's diversity of views about what is valuable. But Warnke is right in asserting that Rawls underestimates the depth of this diversity:

[T] "fe "fact of pluralism" is not a fact just about diversity of general moral, religious and philosophical doctrines in a modern democracy. Nor is it a fact just about the principles, institutional arrangements and practices that best realize the meaning of its public political culture. It is also a fact about our different understandings of the meaning of that public political culture itself, about the meaning, for instance, of such ideas and principles as freedom and equality. ${ }^{63}$

Simply put, we understand the meaning and significance of events and institutions differently. A good example of this difference in interpretive vision is the disparate reactions to the verdict in the O. J. Simpson trial by different individuals and groups. The racial difference in reactions to the verdict was particularly startling to many. ${ }^{64}$

60. See GEORGIA WARNKE, JUSTICE AND INTERPRETATION 38-61 (1993).

61. JOHN RAwLS, POLITICAL LIBERALISM (1993). Rawls describes the project this way: "[H] ow is it possible for there to exist over time a just and stable society of free and equal citizens, who remain profoundly divided by reasonable religious, philosophical, and moral doctrines?" Id. at 4. Rawls assumes three facts about the political culture of democratic societies, the first of which he terms "reasonable pluralism." Id. at 36. By this he means that "the diversity of reasonable comprehensive religious, philosophical, and moral doctrines found in modern democratic societies is not a mere historical condition that may soon pass away; it is a permanent feature of the public culture of democracy." Id.

62. Id. at 10.

63. WARNKE, supra note 60 , at 42 .

64. See Martin Gottlieb, Racial Split at the End, as at the Start, N.Y. TIMES, Oct. 4, 1995, at A1; Richard Morin, Poll Reflects Divisions Over Simpson Case: Trial Damaged Image of Courts, Races Agree, WASH. PosT, Oct. 8, 1995, at A31. A Washington Post survey found that the majority of whites disagreed with the verdict while a majority of African-Americans agreed with it. Id. 
For many African-Americans, the acquittal of Simpson was celebrated as a rare instance of a black man accused of a crime who was not beaten by the system. ${ }^{65}$ Because the trial revealed clear racism in the Los Angeles Police Department (LAPD), ${ }^{66}$ many African-Americans saw the case as symbolic of entrenched racism in the LAPD. For them, the refusal to reward police work tainted by such racism with a conviction represented a chance to force change. ${ }^{67}$ For many whites, in contrast, Simpson's acquittal symbolized how wealth affects outcomes in the criminal justice system. ${ }^{68}$ Moreover, for many white women, the domestic violence obscured the issues of both race and wealth so that Simpson's acquittal represented yet another abusive husband who was not punished and another abused spouse whom the law was unable to protect. ${ }^{69}$

If Warnke's point-which is illustrated by the diversity of reactions to the Simpson verdict-is correct, then we should

65. See Ernest Tollerson, Blacks View Simpson Case in Context of the Past, N.Y. TIMES, Oct. 10, 1995, at A14 (reporting that many blacks see Simpson as "a black man who managed to survive his passage through a rigged system of criminal justice"); Reaction to O.J. Verdict Exposes Chasm Between Blacks, Whites, SUN-SENTINEL (Fort Lauderdale, Fla.), Oct. 8, 1995, LEXIS, News Library, Sunsen File (reporting that "[t]his time, blacks are saying, ... a black defendant could play the game, countering expert with expert. A system devised, implemented and enforced primarily by whites worked as it should this time-regardless of race-and it was, said those rejoicing, a moment to savor and celebrate").

66. See Reaction to O.J. Verdict Exposes Chasm Between Blacks, Whites, supra note 65 (reporting that many interviewees believed the Simpson trial showed racism).

67. When asked about defense lawyer Johnnie L. Cochran, Jr.'s appeal to the jury in his closing argument to send a message about racism with their verdict, $69 \%$ of whites thought that race was used inappropriately while $64 \%$ of blacks and $47 \%$ of Latinos thought this use of race appropriate. Cathleen Decker, The Times Poll: Most in County Disagree with Simpson Verdicts, L.A. TIMES, Oct. 8, 1995, at A1.

68. According to the Atlanta Constitution, "[p]olls in the wake of Simpson's acquittal portray American public opinion fractured along racial lines. Many whites clamor for reforming the jury system; many blacks call for cleaning up police and prosecutors." Jim Yardley, Around the South: Race Matters, ATLANTA CONST., Oct. 15, 1995, at H9.

69. See Decker, supra note 67, at A36. A 1995 Los Angeles Times poll found that women who believed Simpson committed the killings were more likely than men who believed the same to cite Simpson's abuse of Nicole Brown Simpson as their reason for believing that he was guilty of the murder. Id. While women were generally more sympathetic to Simpson than men, they were also more likely to see the murder as a continuation of the domestic violence. Id.; see also Isabel Wilkerson, Whose Side to Take: Women, Outrage And the Verdict on O.J. Simpson, N.Y. TIMES, Oct. 8, 1995, § 4, at 1. 
expect deep disagreement about the meaning of laws and policies challenged on Equal Protection grounds. Our different experiences in the world affect what aspects of an event we find salient and thus how we understand and situate that event relative to the rest of history and culture. My view of how judges should decide among competing interpretations of a law's meaning attempts to take these differences in our perceptions as seriously as Rawls takes our differences in what we value.

This recognition leads me to the following conception of how the judge must determine the meaning of state actions. The first criterion the judge should employ is coherence. The interpretation given to a practice must, to borrow Ronald Dworkin's terminology, "fit" other aspects of the social world of which the practice is a part. $^{70}$ Those interpretations that cohere with more extensive aspects of the social reality, which make sense of them as well as of the particular practice whose meaning is being evaluated, are better for that reason. For example, describing de jure racial segregation as a stateimposed caste hierarchy is a better reading of the expressive character of that practice than the more innocuous interpretation offered by Justice Brown in Plessy because the caste interpretation also explains the disparity in wealth and status between blacks and whites at the time. The caste interpretation fits the broader social reality and provides an explanation of that reality.

The coherence criterion is important, but it will not be sufficient to eliminate disagreement about the meaning of contested practices. After all, a judge's experience of other aspects of the social reality with which he attempts to cohere his interpretation of a particular practice will, necessarily, be partial. I do not mean to suggest that all judges are biased (using that term pejoratively as a deviation from proper exercise of the judicial craft). Rather, a judge, like any other person, cannot transcend, at least not fully, the partiality of his individual perspective. He cannot achieve complete objectivity or as Thomas Nagel might say, a "view from nowhere."71

One common response to the necessary partiality of individual judgment is to attempt to strip away one's particular experiences and values when judging. This approach is

70. DWORKIN, supra note 27, at 230-32.

71. THOMAS NAGEL, THE VIEW FroM NOWHERE 60-66 (1986). 
analogous to that advanced by Rawls in $A$ Theory of Justice as a model of how one ought to think about questions of justice. ${ }^{72}$ According to Rawls, the principles that people would choose if they were behind what he calls a "veil of ignorance" are those that are just. ${ }^{73}$ This veil blinds us to all particular facts about ourselves like our race, sex, age, and abilities, as well as our values, beliefs, and commitments. ${ }^{74}$ While Rawls's approach to thinking about justice surely taps important intuitions about fairness, it is not useful as a model of how to escape partiality in interpretive judgments.

Remember the task at hand is to determine the meaning of a social practice like single sex bathrooms. We cannot pose this question in the abstract, as the Rawlsian approach envisions. When we situate ourselves nowhere, we may be able to think about abstract questions of justice and fairness, though some commentators dispute even this, ${ }^{75}$ but we surely cannot think about what a particular cultural practice means. We can only address that question from within the culture of which the practice is a part because it is the culture that gives the practice its meaning.

If the judge cannot escape partiality through abstraction, then how else can partiality be avoided? Perhaps the judge could base his determination of the expressive dimension of law on what the majority of people find the meaning of a practice to be. This approach casts the judge as sociologist. He gathers data about how members of society perceive a particular law or policy. While this method would help to avoid the fact that the individual judge's perception is but one, necessarily partial, interpretation of meaning, it too is flawed. Equal Protection is especially important for the protection of minority interests. After all, the majority generally has little to fear from legislative action. But if the expressive character of law is determined by adding up the perceptions of all, then minority perceptions may go unprotected. If the majority simply does not see how a law or policy denigrates others, the minority will have no recourse, making the Clause useless in many of the instances when it is most necessary.

72. See RAWLS, supra note 20 , at $17-22,136-42$.

73. Id. at 136. As Rawls explains, "[ $t]$ he idea of the original position is to set up a fair procedure so that any principles agreed to will be just." Id.

74. Id. at 137.

75. See, e.g., Michael J. SANDEL, LIBERALISM AND THE LIMITS OF JUSTICE 175-83 (1992). 
Thus, the partiality of the particular judge's perspective cannot be ameliorated by either abstraction or deferral to the views of the majority. Ideally, interpretation of the expressive dimension of law would be a communal project. We best rectify the partiality of individual perspectives by including the views of others. But rather than simply summing up how the majority perceives an event or practice, the expressive dimension of a law or policy is best understood as the meaning that we would arrive at if we were to discuss the interpretive question together under fair conditions. I borrow this conception of objectivity from the work of Jurgen Habermas. ${ }^{76}$ The basic idea is that members of a society come together to discuss the meaning of a law or practice under conditions in which all are equally able to contribute to the discussion and all are committed to hearing and learning from the views of others. The relevant meaning is the interpretation that this process would produce. ${ }^{77}$

According to Habermas, such a process would yield a unique result. Other scholars disagree with Habermas on this point. ${ }^{78}$ While the question of whether or not discourse under fair conditions would yield consensus is an important philosophical question, it is not necessary to decide that question here since it is a question at the level of ideal theory. In the real world in which these ideal conversational conditions are approximated at best, there will be persistent disagreement. So let us leave the metaphysical question, important though it is, unanswered for the time being and proceed to determine how the judge might best approximate this ideal conversation and thus get as close as possible to the objective meaning of laws.

The judge must make an interpretive judgment about what a particular state action expresses but in doing so should listen closely and with an open mind to the views of others. If the

76. See JURGEN HABERMAS, MORAL CONSCIOUSNESS AND COMMUNICATIVE ACTION (Christian Lenhardt \& Shierry Weber Nicholsen trans., MIT Press 1990) (1983).

77. Id. at 43-115. Habermas defends his detailed conditions-of which the above is a rough approximation-on the grounds that they are the assumptions to which all speakers who wish to actually convince others implicitly agree. In his terms, these rules are the "pragmatic presuppositions" of "communicative action." Id. at 69.

78. See, e.g., WARNKE, supra note 60 , at 154 (arguing that "from a hermeneutic point of view, there is no reason either to expect a unitary interpretation of any meaning, whether social or textual, or to want one"). 
theory espoused in this Article were adopted, then the briefs of parties and amici to a case would directly address the question of what a law or policy expresses. While the exchange of briefs before a court is surely not an instance of ideal discourse, this process is not too imperfect, given the difficulty of the task of resolving complex disagreements in a large and diverse society. In other words, real world constraints make constitutional litigation and the academic commentary it engenders a decent approximation of one iteration of an ideal conversation about the public meaning of state actions.

This brings me to my final point. We should remember that a court's ruling on what a law or policy expresses, even the Supreme Court's, is not the last word. We have not failed, in our theory or in our actual practices, if the Court does not arrive at an objective meaning when it rules on such questions. Rather, we should understand Court rulings on the meaning of governmental actions or practices as one volley, albeit an important one, in an ongoing conversation. While judges should strive to learn from the perspectives of others when interpreting the expressive character of law-in other words, they should aim to achieve as much objectivity in their judgments as possible-the rest of us should remember that their pronouncements are but part of a discourse. It is a discourse to which we can all contribute, which is necessarily ongoing, and from which we, as individuals and as a community, hope to learn over time.

\section{THE EXPRESSIVE DIMENSION OF LAW IN OTHER CONTEXTS}

While the Equal Protection analysis proposed in this Article might feel somewhat unfamiliar, its emphasis on the expressive content of governmental action is not without precedent in constitutional doctrine. In fact, several scholars have recently called attention to developments in other doctrinal fields in which emerging doctrine focuses on the meaning of state action. Some laud these developments, like Richard Pildes ${ }^{79}$ and Charles Lawrence. ${ }^{80}$ Others criticize them, like Matthew Adler, ${ }^{81}$ Jamin Raskin, ${ }^{82}$ Michael

79. See Richard Pildes, Why Rights Are Not Trumps: Social Meanings, Expressive Harms, and Constitutionalism, 27 J. LEGAL STUD. 725 (1998); Pildes \& Niemi, supra note 55.

80. See Lawrence, supra note 12.

81. See Matthew D. Adler, Expressive Theories of Law: A Skeptical Overview, 148 U. PA. L. REV. 1363, 1364 (2000). 
McConnell, ${ }^{83}$ and Steven Smith. ${ }^{84}$ These scholars primarily point to developments in the Establishment Clause and voting rights areas, as examples of doctrinal approaches that have recently been described as "expressivist." 85 Because these scholars have already done a thorough job describing these doctrinal developments, they are only briefly explained here. The purpose is to demonstrate that the Equal Protection theory put forward in this Article has affinities to doctrinal developments in other constitutional fields. ${ }^{86}$

Following Justice O'Connor's concurrence in Lynch $v$. Donnelly, 87 the Supreme Court has begun to judge whether state displays of religious symbols violate the Establishment Clause by looking at whether these displays convey an endorsement of religion. In Lynch, in which the Court reached the counterintuitive conclusion that the display of a crèche in the city's main shopping district in Pawtucket, Rhode Island did not violate the Establishment Clause, O'Connor argued that "[w]hat is crucial is that a government practice not have the effect of communicating a message of government endorsement or disapproval of religion. It is only practices having that effect, whether intentionally or unintentionally, that make religion relevant, in reality or public perception, to status in the political community." 88

In County of Allegheny $v$. ACLU, ${ }^{89}$ in which the majority condemned a city's inclusion of a crèche but permitted its inclusion of a menorah in holiday displays in the city, Justice Blackmun for the Court explicitly adopted O'Connor's endorsement test from Lynch..$^{90}$ According to Blackmun's

82. See Jamin B. Raskin, The Supreme Court's Racial Double Standard in Redistricting: Unequal Protection in Politics and the Scholarship That Defends It, 14 J. L. \& PoL. 591 (1998).

83. See Michael McConnell, Religious Freedom at a Crossroads, 59 U. CHI. L. REV. 115 (1992).

84. See Steven D. Smith, Symbols, Perceptions, and Doctrinal Illusions: Establishment Neutrality and the "No Endorsement" Test, 86 MrCH. L. REV. 266 (1987).

85. E.g., Adler, supra note 81, at 1438 (Establishment Clause); Raskin, supra note 82 , at $635-36$ (voting rights).

86. For a more thorough analysis of the pros and cons of these expressivist conceptions of Establishment Clause and voting rights questions, consult the articles cited supra note 85.

87. 465 U.S. 668 (1984).

88. Id. at 692 (O'Connor, J., concurring) (emphasis added).

89. 492 U.S. 573 (1989).

90. Id. at 573 . 
understanding of that approach, "the government's use of religious symbolism is unconstitutional if it has the effect of endorsing religious beliefs, and the effect of the government's use of religious symbolism depends upon its context." 1 Using that approach, Blackmun found that setting the menorah next to a Christmas tree and a sign saluting liberty neutralized any message of endorsement of Judaism that the symbol might otherwise convey, ${ }^{92}$ whereas the crèche appeared unadorned, thereby retaining its religious meaning..$^{93}$

Similarly emphasizing the expressive content of the state action, the Court in Shaw v. Reno ${ }^{94}$ held that the redistricting of one of North Carolina's congressional districts violated the Equal Protection Clause because the district's bizarre shape sent the message that race played too dominant a role in the drawing of district lines. ${ }^{95}$ Justice O'Connor's opinion for the Court stressed that "reapportionment is one area in which appearances do matter." ${ }^{.96}$ A legislature may take race into account in districting, ${ }^{97}$ but "[i]n some exceptional cases, a

91. Id. at 597. In Pittsburgh, Allegheny County, the crèche was displayed on the grand staircase of the County Courthouse while the menorah was displayed outside the City-County building and surrounded by a Christmas tree and a sign saluting liberty. Id. at 578. Some readers may find Blackmun's understanding of the meaning of each of these symbolic displays puzzling. Does not a menorah also express that one religious group has a special place in the political community? For the Court, however, the display of the menorah, the tree, and the sign together symbolized the city's recognition of the secular aspects of the holidays as winter festivals and the common theme of light and religious liberty. Id. at 619. I do not intend to weigh in on that question here. What is important for our purposes is that the Court examined the expressive content of the state action in order to assess its constitutional permissibility. The theory readily acknowledges that people will disagree about the best understanding of what particular state actions in fact express. See supra Part II.C.

92. Allegheny, 492 U.S. at 617-18.

93. Id. at 598-99.

94. 509 U.S. 630 (1993).

95. Id. at 658. I mention Shaw in order to point out another area within constitutional law in which the social meaning of governmental action is taken to be significant. While I commend the Shaw Court for attending to the importance of the expressive dimension of state action, I believe that the Court draws the wrong conclusion from that meaning. My theory instructs that only when the meaning that state action expresses conflicts with the principle of equal concern is Equal Protection violated. As I do not believe that the redistricting plan at issue in Shaw sends a message at odds with the equal concern principle, I would uphold the plan as is.

96. Id. at 647 .

97. See id. at 646 (arguing that legislators can't help but be aware of race and that "[t]hat sort of race consciousness does not lead inevitably to 
reapportionment plan may be so highly irregular that, on its face, it rationally cannot be understood as anything other than an effort 'to segregat[e] . . v voters' on the basis of race." ${ }^{.98}$ In assessing how the district will be seen and "rationally... understood," the Court makes a judgment about what the district's shape expresses. ${ }^{99}$

According to commentators Richard Pildes and Richard Niemi, Shaw recognizes an "expressive harm ... [that] results from the ideas or attitudes expressed through a governmental action, rather than from the more tangible or material consequences that action brings about." 100 In Shaw, there were no allegations of vote dilution, thus no concrete harm to white voters as a result of the oddly shaped majority-minority district. Moreover, while the legislators clearly took race into account in drawing the districts, the Court held that this was permissible. So, in Shaw there was neither invidious intent nor material harm. The redistricting plan was nonetheless held to violate Equal Protection because, according to Pildes and Niemi, "[w] hat matters is the social message their action conveys."101

The careful reader has surely not missed the common thread that links the Establishment Clause cases with Shaw: Justice O'Connor. An earlier opinion from another doctrinal field and jointly written by Justices O'Connor, Kennedy, and Souter adopts a similar concern with the expressive dimension of actions. In Planned Parenthood v. Casey, ${ }^{102}$ in which the Court reaffirmed the basic holding of Roe $v$. Wade 103 that a woman has a constitutional right to abort a fetus before it

impermissible race discrimination").

98. Id. at 646-47 (citation omitted).

99. In the two later iterations of Shaw-Shaw v. Hunt, 517 U.S. 899 (1996) [Shaw II], and Hunt v. Cromartie, 526 U.S. 541 (1999)-the Court does seem to back away from the conception of the violation as rooted in what the shape of the district expresses. For example, in Shaw II, Justice Rehnquist's opinion for the Court maintains that "[t]he plaintiff bears the burden of proving the race-based motive and may do so either through 'circumstantial evidence of a district's shape and demographics' or through 'more direct evidence going to legislative purpose." 517 U.S. at 905 (quoting Miller v. Johnson, $115 \mathrm{~S}$. Ct. 2475, 2488 (1995)).

100. Pildes \& Niemi, supra note 55, at 506. See generally Raskin, supra note 82, for an account critical of the recognition of this expressive harm in Shaw.

101. Pildes \& Niemi, supra note 55, at 508.

102. 505 U.S. 833 (1992).

103. 410 U.S. 113 (1973). 
reaches viability, the plurality opinion grounded its decision to reaffirm Roe on, in part, the expressive significance that overruling Roe would have. ${ }^{104}$ As I have argued elsewhere, 105 the plurality asserted that stare decisis, correctly applied, required the Court to consider whether a decision to overrule a previous case would seem unprincipled. ${ }^{106}$ In each of these doctrinal fields, the Court has adopted the view that the public meaning of state action has constitutional significance.

\section{E. SitUATING THIS THEORY}

In the theory presented in this Article, many readers will hear the familiar echo of Charles Black who, in his insightful 1960 article The Lawfulness of the Segregation Decisions, ${ }^{107}$ argues that segregation is unlawful because of its social meaning. Black's piece is best understood as a response to Herbert Wechsler's provocative critique of the Court's reasoning in Brown v. Board of Education. ${ }^{108}$ For Wechsler, the material equality of the segregated schools (as stipulated by the parties) meant that "the question posed by state-enforced segregation [was] not one of discrimination at all."109 Rather, for Wechsler, the case required the Court to choose between the rights of African-Americans to free association and the rights of whites to avoid association. ${ }^{110}$

For Wechsler, abstraction is a virtue in constitutional principles. In his terms, such principles are thereby more "neutral" and thus judicial decision-making more legitimate. ${ }^{111}$

104. The plurality instructed that the Court must make sure that overruling in politically sensitive cases can be understood by "the thoughtful part of the Nation" as the Court's "constitutional duty" and "not merely as the victories of one doctrinal school over another by dint of numbers." Casey, 505 U.S. at 864 .

105. See generally Deborah Hellman, The Importance of Appearing Principled, 37 ARIZ. L. REV. 1107 (1995).

106. See Casey, 505 U.S. at 860-70.

107. Black, supra note 6.

108. See Herbert Wechsler, Toward Neutral Principles of Constitutional Law, 73 HARV. L. REV. 1, 31-35 (1959).

109. Id. at 34. In fact, Wechsler even goes so far as to endorse the Plessy view: "In the context of a charge that segregation with equal facilities is a denial of equality, is there not a point in Plessy in the statement that if 'enforced separation stamps the colored race with a badge of inferiority' it is solely because its members choose "to put that construction upon it?" Id. at 33 (quoting Plessy v. Ferguson, 163 U.S. 537, 551 (1896)).

110. See id. at 33-34.

111. See id. at 9-10. 
This attachment to abstraction makes Brown a problem for Wechsler. He sees no way to choose between the two free association claims. To put this problem in terms of the examples used in this Article, any principle that would strike down racial segregation of public schools would also invalidate single-sex bathrooms in state buildings. Unable to accept the latter, Wechsler believes his neutrality principle requires him to reject the former as well.

Black's response, which I build upon today, is that Wechsler's lauded abstraction provides a false sense of neutrality and legitimacy; it is flawed because it is unable to see and grasp incontestable facts about our world. Black instructs:

[I]t would be the most unneutral of principles, improvised ad hoc, to require that a court faced with the present problem refuse to note a plain fact about the society of the United States-the fact that the social meaning of segregation is the putting of the Negro in a position of walled-off inferiority. ${ }^{112}$

Abstraction is not always problematic. But where the question at issue is inherently interpretive, as this Article argues that issues of discrimination are, then abstraction will fail to provide better answers. A method that requires abstraction, like Wechsler's, will itself only produce " $a d$ hoc" and consequently illegitimate results because it is unable to consider those facets of our world whose significance can only be grasped by understanding their meaning-an inherently contextual task.

Wechsler's method can see only textbooks, salaries, and buildings. Black's method looks at those things as well as the meanings that different arrangements of physical reality produce. Black poses the question of Brown as "whether discrimination inheres in that segregation which is imposed by law in the twentieth century in certain specific states in the American Union," a question whose answer requires that judges attend to "history and ... common knowledge."113 For example, differences in teacher salaries and textbooks matter in judging equal treatment, whereas differences in the colors of school walls do not because in our culture lower salaries are indicative of less teacher quality and given the way our schools work, it is harder for students to learn with fewer textbooks. Textbook numbers are not inherently more real or more

112. Black, supra note 6 , at 427 .

113. Id. 
significant for equality purposes than is wall color or the racial make-up of the students. Rather, each is relevant or irrelevant given the way we do things in our culture. In other words, in order to know which differences matter, which to abstract away and which to keep as constant or treat as irrelevant in forming an abstract judgment, one must employ a theory about what differences matter to the project at hand.

Black starts our equality jurisprudence off in the right direction by emphasizing the importance of the expressive dimension of law in assessing equal treatment. His important contribution is his quite effective reply to Wechsler. Unfortunately, the insight that the expressive content of governmental action is at the heart of Equal Protection has not garnered the support either of the majority of scholars or of the courts. ${ }^{114}$ Instead, the dominant reply to Wechlser's problematization of Brown has been a turn toward intent-based analysis. ${ }^{115}$ While that approach may have seemed satisfactory initially, as the example of de jure segregation is overdetermined-the product of bad intentions as well as a practice with a noxious meaning-an intent-based approach has other problems that have been extensively developed by others. ${ }^{116}$ Unfortunately, while Wechsler's critique of Brown led scholars to search for a new doctrine to support the holding of Brown, Black's reply to Wechsler was not the source of their inspiration.

Edwin Baker picks up Black's mantle 23 years later in his article Outcome Equality or Equality of Respect: The Substantive Content of Equal Protection. ${ }^{117}$ Baker argues for

114. A survey of law review articles from 1960, when Black's piece was written, until today shows few scholars either adopted or extended his approach. Notable exceptions include those discussed in the text above.

115. Black himself seems to emphasize the importance of improper purpose at times as well. For example, in a well-known passage he writes,

[b] ut if a whole race of people finds itself confined within a system which is set up and continued for the very purpose of keeping it in an inferior station, and if the question is then solemnly propounded whether such a race is being treated 'equally,' I think we ought to exercise one of the sovereign prerogatives of philosophers-that of laughter.

Black, supra note 6 , at 424 . Black's article is important because it calls attention to the centrality of social meaning although it admittedly does not further develop that insight into a complete philosophical account.

116. See supra notes 11-14.

117. 131 U. PA. L. REV. 933 (1983). I am grateful to Baker for sending his article to me after I presented an earlier version of this piece at a Legal Theory Workshop at the University of Pennsylvania Law School in March of 
an "equality of respect" conception of Equal Protection which he defines as consisting of three principles. ${ }^{118}$ The first is a political participation principle that requires each person be able to fully and meaningfully participate in political life. ${ }^{119}$ The third requires that each person be entitled to those opportunities or resources that society understands as basic. 120 But it is his second principle that is most relevant for the argument presented in this Article. According to Baker, "the state must not pursue purposes, and the political process must not further individuals' preferences, to subordinate or to denigrate the inherent worth of any category of citizens."121 Notably, Baker understands this second principle as a function of the expressive character of governmental action.

Baker's provocative claim is this: when the Court speaks about purpose or intent in the Equal Protection context, as in striking down state laws enacted with invidious intent, we should understand that intent objectively rather than subjectively. Baker's "objective intent" is remarkably close to my understanding of the expressive character of a law. To find objective intent, Baker thinks that the Court "looks to a social context in which we understand human actions and artifacts; the inquiry determines the purpose of the law or act on the basis of socially understood contextual factors and human practices."122 For Baker, this is both a descriptive and a prescriptive claim. Descriptively, Baker believes that many Equal Protection cases that invalidate laws do so on the basis of the objective rather than subjective intent of those who enacted the laws. ${ }^{123}$ Prescriptively, he believes this is the right approach and indeed hopes and projects that it will become more common. ${ }^{124}$

Since Baker wrote his article in 1983, his descriptive claim is that as of 1983, the Court used objective intent to decide Equal Protection claims. While Baker surely is right that the Court is not at all clear in articulating what it means by

1999.

118. Id. at 959.

119. Id.

120. Id.

121. Id.

122. Id. at 973.

123. See id. at 972-73.

124. See id. at 998. 
intent, 125 he overstates in claiming that objective intent is already dominant. ${ }^{126}$ As in any complex doctrinal field, there are tensions and even contradictions between cases. ${ }^{127}$ While some cases do support Baker's account, ${ }^{128}$ the Court continues, in the main, to cleave to subjective intent, ${ }^{129}$ and commentators continue to treat that view as dominant. ${ }^{130}$

125. Baker cites Michael M. v. Superior Court, 450 U.S. 464 (1981), as an example of a case in which the Court rejects the importance of evidence of subjective intent. Baker, supra note 117 , at 979.

126. The cases cited by Baker as evidence for his descriptive claim include Rogers v. Lodge, 458 U.S. 613 (1982), Michael M., 450 U.S. 464, Personnel Administrator v. Feeney, 442 U.S. 256 (1976), and Palmer v. Thompson, 403 U.S. 217 (1971).

127. Baker of course acknowledges this fact. Indeed, his claim is that on balance, objective intent is emerging as the dominant focus in Equal Protection cases. See Baker, supra note 117, at 972-73. As Baker notes, the Court uses several terms that together denote a range from subjective intent to objective meaning: "The words 'intent,' 'motive,' 'purpose,' 'meaning,' and 'function' suggest a rough continuum that moves from 'subjective purpose' and an emphasis on mental states to 'objective purpose' and an emphasis on social context." Id. at 973.

128. See, e.g., infra notes 131-135 and accompanying text (discussing Mississippi University for Women v. Hogan).

129. See, e.g., Miller v. Johnson, 515 U.S. 900, 916 (1995) ("The plaintiffs burden is to show, either through circumstantial evidence of a district's shape and demographics or more direct evidence going to legislative purpose, that race was the predominant factor motivating the legislature's decision to place a significant number of voters within or without a particular district."); Hunter v. Underwood, 471 U.S. 222, 227, 229 (1985) (determining whether a criminal statute was enacted with discriminatory intent and noting that "the crimes selected for inclusion in $\S 182$ were believed by the delegates to be more frequently committed by blacks"); Feeney, 442 U.S. at 279 ("[D]iscriminatory purpose'... implies more than intent as volition or intent as awareness of consequences. It implies that the decisionmaker ... selected or reaffirmed a particular course of action at least in part 'because of,' not merely 'in spite of,' its adverse effects.") (footnotes and citation omitted).

130. See, e.g., Andrew Koppelman, Romer v. Evans and Invidious Intent, 6 WM. \& MARY BILL RTS. J. 89, 93 (1997) (arguing that "the concept of purpose" is "fundamental to the adjudication of equal protection claims"); Louis S. Raveson, Unmasking the Motives of Government Decisionmakers: A Subpoena for Your Thoughts?, 63 N.C. L. REV. 879, 963 (1985) (discussing whether courts apply objective or subjective standards of intent and noting that "[t]he Supreme Court seems to have articulated a subjective standard of intent"). Some scholars do argue that while the Court expressly endorses adherence to a subjective intent standard, in practice it employs a more complex approach. See, e.g., David Crump, Evidence, Race, Intent, and Evil: The Paradox of Purposelessness in the Constitutional Racial Discrimination Cases, 27 HOFSTRA L. REV. 285, 289 (1998) (arguing that the "concept of discriminatory 'intent' or discriminatory 'purpose' takes on different, shifting meanings in different opinions, and it includes unconscious or accidental discrimination in some cases"); Ortiz, supra note 4, at 1107 (arguing that rather than 
The strongest example of Baker's descriptive claim is Justice O'Connor's opinion for the Court in Mississippi University for Women v. Hogan. ${ }^{131}$ In Hogan, O'Connor invalidated Mississippi's support of an all-female nursing school because that state action communicated a message fraught with "archaic and stereotypic notions" that women "are presumed to suffer from an inherent handicap or to be innately inferior."132 Whatever the subjective intention of the state actors supporting the Mississippi University for Women (MUW) School of Nursing, O'Connor was interested in the policy's objective meaning: that women are well-suited for nursing but not for other avocations. She grounded her opinion on the expressive character of state support for this school, a meaning incompatible with the principle of equal concern. ${ }^{133}$

Interestingly, Justice Powell's dissenting opinion took issue with whether O'Connor's reading of what the policy expressed was indeed correct but not with whether looking at meaning (objective intent) was the right way to evaluate the case.134 Powell pointed out that Mississippi also supported two other co-educational nursing schools and that since the nursing school was added to what was already a single sex institution (indeed MUW has been all female since 1884), "[t]his hardly supports a link between nursing as a women's profession and MUW's single-sex policy."135 In other words, given these facts, the objective meaning of Mississippi's support of the MUW School of Nursing was not as O'Connor characterized it. What is important about Hogan is not whether O'Connor or Powell made the better interpretive judgment about the meaning of Mississippi's support of MUW. Rather, it is the fact that both Justices rested their decisions on the expressive content of the state's action that makes this case relevant to Baker's claim.

"regulating the inputs to decisionmaking"-subjective intent-"intent serves ... as a way of judging substantive outcomes").

131. 458 U.S. 718 (1982). Note that it is again Justice O'Connor who stresses the importance of the expressive dimension of state action.

132. Id. at 724-25.

133. Justice O'Connor explained the problem with the single-sex admissions policy at MUW in this way: "Rather than compensate for discriminatory barriers faced by women, MUW's policy of excluding males from admission to the School of Nursing tends to perpetuate the stereotyped view of nursing as an exclusively woman's job." Id. at 729. The problem with the policy inheres in what it expresses (nursing is a women's job) not in the actual selective motives of those who enacted the policy. Id.

134. See id. at 735-45 (Powell, J., dissenting).

135. Id. at 743 (Powell, J., dissenting). 
Hogan is a nice illustration of how Equal Protection analysis would function if an expressive conception of that Clause were adopted. While Baker exaggerates in claiming Equal Protection doctrine was already focusing on objective rather than subjective intent in 1983, pointing out where the Court has adopted this approach so far is a valuable contribution. But how influential has Hogan been?

A quick review of Equal Protection cases post-1983 reveals that courts do not look to objective intent in order to determine if a law is constitutionally permissible. Rather, intent continues to be understood subjectively. For example, in the 1985 case Hunter $v$. Underwood, ${ }^{136}$ the Court invalidated an Alabama law that disenfranchised persons convicted of crimes "involving moral turpitude" on the grounds that "the crimes selected for inclusion in [the disputed section] were believed by the delegates to be more frequently committed by blacks."137 The evidence provided to support this claim consisted of testimony of historians as to the actual motivations of those who enacted the law. ${ }^{138}$ More recently, in Romer v. Evans, ${ }^{139}$ the Court struck down an amendment to the Colorado Constitution that prohibited the enactment of local laws protecting gay men and lesbians from discrimination on the grounds that "[t]he breadth of the Amendment is so far removed from [the justifications offered for it] ... that we find it impossible to credit them."140 Instead, the Court found, via an "inevitable inference," that "the disadvantage imposed is born of animosity toward the class of persons affected." 141 In current case law, then, subjective intent continues to be the crucial factor.

In a more recent article, Todd Rakoff puts forward a view that is similar to Baker's but defends it on more modest grounds. ${ }^{142}$ Rakoff argues that we ought to import the objective conception of intent derived from the law of contracts into Equal Protection doctrine.143 Moreover, Rakoff, like this author, believes that current doctrine focuses on subjective

136. 471 U.S. 222 (1985).

137. Id. at 227.

138. Id. at 228-29.

139. 517 U.S. 620 (1996).

140. Id. at 635 .

141. Id. at 634 .

142. Rakoff, supra note 14.

143. See id. at 76-79. 
intent. State action violates the Clause if it is adopted for the wrong reasons: "The doctrine requires proof of discriminatory state of mind on the part of particular officials."144 More importantly, Rakoff believes that it is objective intent or "social meaning" (Rakoff uses the terms interchangeably) that ought to matter. ${ }^{145}$

Rakoffs critique is avowedly modest in that he does not intend to articulate or defend a particular contested conception of what Equal Protection protects. ${ }^{146}$ Instead, he argues for a doctrinal shift in order to better fulfill understandings of the Clause that he takes as given. Following a thoughtful critique of both the intent- and impact-based understandings of Equal Protection, Rakoff argues that we should judge the constitutionality of state actions by looking at their objective meaning. ${ }^{147}$ He points out that the shift from the subjective to the objective theory of intent in contract law followed the emergence of corporate or institutional actors whose subjective intent is at most metaphorical. It is thus at least anomalous and at most absurd that "[i]n making the most public determination possible in our legal system-testing official action, including the most general of statutes, for constitutional validity-the state of mind of individuals is thought to be crucial" whereas "[i]n making the most private determination possible-construing the terms of an individualized agreement made between two human beings-the social meaning of what they have done becomes the test." 148

The theory advanced in this Article clearly falls in the tradition of Charles Black, a tradition that has been intermittently followed by others like Baker, Charles Lawrence, and Rakoff. In this vein, Equal Protection is understood as a function of the expressive dimension of governmental action. While Baker and Rakoff use the term "objective intent" to describe what I would call "the expressive character" of governmental action, both men understand these terms interchangeably. ${ }^{149}$ Recently, this approach to

144. Id. at 64 .

145. See id. at 71, 79, 81-88, 91-92, 95 (using the term "social meaning"); id. at 84 (using the concepts of objective intent and social meaning interchangeably).

146. See id. at 63 .

147. Id. at 79.

148. Id. at 81 .

149. But see discussion of Andrew Koppelman's understanding of "objective 
constitutional law has been experiencing a modest renaissance, heralded most forcefully by Richard Pildes. Pildes has explained Shaw $v$. Reno's ${ }^{150}$ rejection of South Carolina's twelfth congressional district on the basis of the meaning of its elongated shape. ${ }^{151}$ More recently still, Pildes, together with the philosopher Elizabeth Anderson, published a comprehensive defense of expressive theories of law. ${ }^{152}$

Pildes' central contribution is to recognize that the expressive aspect of governmental action is constitutionally significant. ${ }^{153}$ For Pildes, the heart of the violation in Shaw, and other cases in which he employs his approach, is that certain reasons for action are proscribed within certain contexts. Focusing on the whole of constitutional law, rather than just Equal Protection, he notes that "constitutional scholars are increasingly coming to assert that judicial decisions turn less on the material effects state action produces and more on distinguishing permissible from impermissible justifications for state action."154

This focus on reasons or justifications for action need not necessarily fall in line with the expressive theory of Equal Protection presented here, in that such a theory could find that the subjective motivation of legislators is what matters in assessing the justification for a given law. However, in other work, Pildes is clear that he believes that when assessing whether laws are enacted for the wrong sorts of reasons, courts must look at the meaning of the law and not search for evidence of subjective intent. In an earlier article also coauthored with Elizabeth Anderson, which looks at what effect the insights of social choice theory have on conceptions of democratic deliberation, Pildes and Anderson caution that intent-based analysis ought to be understood as a search for social meaning, not subjective motivation. ${ }^{155}$ As they explain,

[f]ailure to recognize that expressed purposes and states of minds of enacting legislators do not, standing alone, determine the purpose of

intent," infra Part III.B.3.

150. 509 U.S. 630 (1993).

151. See Pildes \& Niemi, supra note 55, at 507.

152. Anderson \& Pildes, supra note 11.

153. See Pildes, supra note 79, at 754-60; Pildes \& Niemi, supra note 55, at 506-16.

154. Pildes, supra note 79 , at 750.

155. Richard H. Pildes \& Elizabeth S. Anderson, Slinging Arrows at Democracy: Social Choice Theory, Value Pluralism, and Democratic Politics, 90 COLUM. L. REV. 2121, 2209 n.240 (1990). 
a governmental act or statute is one of the current problems that plagues the increasingly important area of unconstitutional motivation analysis. Attention to the expressive dimension of collective choices can clarify some of this confusion by emphasizing that the relevant focus of unconstitutional motivation inquiry ought to be what the social meaning of the action is understood to be, that is, whether the action is understood to express disrespect for constitutionally enshrined higher values. ${ }^{156}$

Pildes and Anderson's defense of the importance of the expressive dimension of state action in constitutional law has just begun to engender sustained critique. Previously, attacks on the Court's focus on the meaning of state action have been limited to debates within particular doctrinal fields. These include Jamin Raskin's ${ }^{157}$ attack on the Pildes and Niemi ${ }^{158}$ defense of Shaw and Steven Smith's ${ }^{159}$ attack on Justice O'Connor's focus on meaning in Establishment Clause cases. However, in a recent volume of the Pennsylvania Law Review, Matthew Adler attacks the coherence of expressivist conceptions of law more generally, ${ }^{160}$ and Pildes and Anderson offer a comprehensive reply. ${ }^{161}$ While an extensive discussion of these views is beyond the scope of this Article, it is surely fair to say that this Article presents a theory of Equal Protection which falls into the category of views termed expressivist.

This review of the scholarly literature shows that the theory presented in this Article is squarely in the tradition of Charles Black, whose insights about Equal Protection have, unfortunately, not been followed by the majority of scholars or courts. This Article offers both a development and defense of the view provoked by Black's 1960 piece. I am not alone in this endeavor. The works of Charles Lawrence, Edwin Baker, Todd Rakoff, and most recently Richard Pildes and Elizabeth Anderson also defend the importance of the expressive dimension of governmental action for Equal Protection.

\section{F. OBJECTION: THE PROBLEM Of ELUSIVENESS}

The view advanced in this Article may be objectionable because it appears to diminish the moral force of a claim of

156. Id.

157. Raskin, supra note 82 , at 635-54.

158. Pildes \& Niemi, supra note 55.

159. Smith, supra note 84, at 276-312.

160. Adler, supra note 81, at 1462-93.

161. Anderson \& Pildes, supra note 11. 
wrongful discrimination, to treat it not as a real wrong but as merely a perceived one. I take this objection seriously. This Article puts forward an expressivist account of equality. As such, it demands that we interpret the meaning of state action, for therein resides the wrong. But is this understanding of the constitutional violation too ephemeral?

Let me draw an analogy that may help to make my position both clearer and more palatable to opponents. In an article decrying the interpretive turn in modern philosophy and legal theory, Michael Moore acknowledges that some modest interpretivism has a place in a few well-circumscribed contexts. ${ }^{162} \mathrm{He}$ gives two examples: therapy and courtesy. The second, Moore adopts from Dworkin and is used as part of Moore's critique of Dworkin's interpretivism about jurisprudence. ${ }^{163}$ In Moore's view, interpretivism is appropriate when there is a good reason to treat a text or textanalogue as authoritative; 164 thus, for Moore statutory interpretation is properly an interpretive activity. ${ }^{165}$

Similarly, according to Moore, one rightly determines what counts as a courteous action interpretively because "there is a point justifying why practitioners of courtesy should grant authority to the existing social text (our existing rules of courteous behavior)."166 Moore asserts this because,

[t]o be courteous, one must be understood as trying to be courteous, so that one needs to utilize the existing forms of courtesy to succeed at being seen as being (and thus as being) courteous. This justifies treating the existing rules of courtesy as a kind of text, interpretation of which is to guide courteous behavior. ${ }^{167}$

It is because courteous actions, taking off one's hat, for example, only have meaning in relation to social conventions that the actor who wishes to be courteous must know and work within these conventions. Taking off one's shirt when entering someone's house expresses something vastly different in our culture than taking off one's hat, and this meaning is what makes the first action courteous and the second not. To be

162. See Michael Moore, The Interpretive Turn in Modern Theory: A Turn for the Worse?, 41 STAN. L. REV. 871, 934-46 (1989).

163. Moore does agree that the judge's attitude toward both statutory and constitutional law is properly interpretive. See id. at 948.

164. See id. at 946.

165. See id. at 947.

166. Id. at 946 .

167. Id. 
courteous in a given culture requires that one interprets the conventions of that culture.

What Moore concedes about courtesy is also true of treating people with equal concern and respect, the gravamen of Equal Protection. Think back to Plessy. The Louisiana legislature's failure was that it did not recognize that existing customs shaped the meaning of the state's action. It is because segregation by race in railcars had a particular meaning that such racial segregation violated Equal Protection; it is because segregation by sex in public bathrooms has a very different meaning that it does not violate the Clause. The basic point is this: to treat people with equal concern, government must attend to the expressive dimension of its actions. As Moore makes clear, part of being courteous is being recognized as such by those to whom one is trying to be courteous. Therefore, courtesy requires attention to the meaning that others are likely to attribute to action. Similarly, treating others with equal respect requires that we respect others' views about equal treatment.

\section{G. THE CONTINUED RELEVANCE OF INTENT AND MATERIAL EFFECT}

Another critic might question my rejection of an intentbased theory since surely subjective intent will continue to be relevant in determining objective meaning. But then even under a doctrine that makes subjective intent central, we always look at the objective manifestations of that intent since we never have direct access to subjective intent itself. In this regard, won't both theories look at similar evidence in practice? In large part they will, but for different reasons. If subjective intent is determinative, then we look at evidence to determine what it implies about the actual motivations of lawmakers. If objective meaning is determinative, evidence of subjective intent matters only so long as that evidence contributes to the public meaning of the action. For example, private notes may be good direct evidence of subjective intent but are useless in determining what the law or policy expresses precisely because they are private.

Similarly, the meaning of laws or governmental policies is also, in part, a function of the effects of those laws and policies. If a law denies something to one group that is accorded to another, this fact is important, though not dispositive, in ascertaining the law's meaning. Meaning is a function both of 
the publicly available evidence of intent and of the material effects of laws. These factors have not been excised from the doctrine by the theory proposed here, but their significance has been diminished as compared to either a theory of Equal Protection grounded in invidious intent or one based on material effect, respectively.

\section{H. STANDING}

In those doctrinal areas where expressive injuries have been recognized, voting rights and Establishment Clause claims most notably, the question of standing-who has it and how is it defined-has raised considerable controversy. ${ }^{168}$ The problem is that if the constitutional injury is described as inhering in an impermissible expression by the state actor, isn't everyone, literally everyone, thereby harmed? And if the delineation of the constitutional right determines who has standing, isn't everyone situated, and equally well so, to bring the challenge? Thereby, it seems, the doctrine of standing is eviscerated.

The statement of this problem and the reductio ad absurdum it produces lead to the conclusion that one of the premises must be flawed. To some commentators, the constitutional violation cannot inhere in the expressive action. For example, in the voting rights area, Pamela Karlan argues that only claims of vote dilution ought to be recognized.169 With this definition of the injury, standing is thereby circumscribed. But surely practical problems with standing should not drive our assessment of the nature of constitutional guarantees.

This leads me to try to revise the other premise: that the delineation of the right determines who has standing. Standing may in fact "stand alone."170 In other words, the

168. See, e.g., John Hart Ely, Standing to Challenge Pro-Minority Gerrymanders, 111 HARV. L. REV. 576 (1997); Samuel Issacharoff \& Pamela S. Karlan, Standing and Misunderstanding in Voting Rights Law, 111 HARV. L. REV. 2276 (1998); Gene R. Nichol, Jr., Abusing Standing: A Comment on Allen v. Wright, 133 U. PA. L. REV. 635, 650 n.77 (1985) (explaining that "[p]articularized harm has not been required in establishment clause cases"); Pildes \& Niemi, supra note 55, at 513-16; Smith, supra note 84, at 297-98 (discussing issues of standing in Establishment and Free Exercise cases); Note, Expressive Harms and Standing, 112 HARV. L. REV. 1313 (1999).

169. See Pamela S. Karlan, Still Hazy After All These Years: Voting Rights in the Post-Shaw Era, 26 CUMB. L. REV. 287, 310 (1996).

170. Karlan and Samuel Issacharoff emphatically deny this possibility in their insightful article critiquing Ely's conception of standing in voting rights 
doctrine that defines the constitutional violation need not necessarily be co-extensive with the manner in which standing is defined. As Richard Pildes, who shares this view, explains, "[s]tanding doctrines require that plaintiffs suffer individuated harm before courts are appropriate institutional forums for resolving the dispute ... [b]ut that says little about what range of interests a given right protects once a particular plaintiff is a proper vehicle for vindicating the right."171 The purposes served by the standing requirement are served whether the test for standing is co-extensive with the conception of the right allegedly violated or not.

The challenge then is to define the requirements of standing on their own. If this fails, the other alternative is to deny that the conclusion produced by the reductio is, in fact, absurd. In other words, one can accept a very broad conception of standing in areas of constitutional law where the injury is expressive. This appears to be the "solution" adopted by the Court in some Establishment Clause cases. ${ }^{172}$ Because I believe that the understanding of Equal Protection proposed in this Article is correct, I would accept a similarly broad understanding of standing in Equal Protection cases before I would jettison the theory. But first, let's see if standing can in fact stand alone.

In the Equal Protection context, we will often have a practical method to limit standing because a limited number of people have suffered a concrete harm, though that harm will not form the basis of the constitutional violation. For example, in United States $v$. Virginia, ${ }^{173}$ we ought to assess whether Virginia may support an all-male military academy by testing

cases. See Issacharoff \& Karlan, supra note 168, at 2279.

171. Pildes, supra note 79 , at 733.

172. See Lynch v. Donnelly, 465 U.S. 668, 670-71 (1984) (allowing residents of the City of Pawtucket standing to challenge inclusion of a nativity scene in a City sponsored holiday display). Note, however, that the Court did not actually discuss the issue of standing in its decision. It merely granted certiorari and analyzed petitioners' claims on Establishment Clause grounds without questioning their ability to challenge the City's practice. The Court allowed another challenge in County of Allegheny v. ACLU, 492 U.S. 573 (1989). The Court permitted several residents of the County of Allegheny standing to challenge the constitutionality of a crèche in a county courthouse and Chanukah menorah outside a city and county building as unconstitutional under the Establishment Clause. Id. at 589. Again, the Court did not actually discuss the issue of standing itself. Rather, the Court assumed, without discussion, that the plaintiffs had standing to challenge the holiday display.

173. 518 U.S. 515 (1996). 
the expressive character of that action against the mandate of equal concern. It is surely true that everyone who is informed and paying attention is the recipient of the offending meaning, but not everyone is denied admission or deterred from applying for admission to the Virginia school. Only those who have suffered this concrete harm have standing.

This method of looking at the issue is not dissimilar from what occurs in the Establishment Clause area as well. For example, in Lee $v$. Weisman ${ }^{174}$ the Court ruled that nonsectarian prayer at a middle or high school graduation service violates the Establishment Clause. ${ }^{175}$ In Lee the violation-the endorsement of religious prayer by the state through the public school-is one that harms everyone. But standing was grounded on the fact that Deborah Weisman, the minor challenger, would graduate from high school and therefore be forced to listen to the offending prayer if she wanted to attend her graduation. The Court did not treat this harm as expressive and did not explicitly use the endorsement test of Lynch and Allegheny, but it is easy to understand the violation in those terms. In Lee the state endorsed religion by sanctioning prayer. The violation was this offending expression. But only students attending the school had standing, the concrete injury required to assure a vigilant litigant, to bring the challenge.

This conception of standing also makes sense if we remember the nature of these expressive violations. The state may not express that some people are less worthy than others (Equal Protection) or that some religious beliefs are superior to others (Establishment Clause). The violation is the failure by the state to comply with this prohibition; it does not require that any person be harmed thereby. Remember the example given earlier of segregating care facilities for incompetent patients by race. ${ }^{176}$ This example illustrates the claim that the violation inheres in the prohibited expression, regardless of whether anyone is stigmatized. Since stigma or injury is not necessary to the violation, it cannot form the basis of standing. We must define our standing requirements in another manner, a manner designed to meet the goals of that doctrine alone.

174. 505 U.S. 577 (1992).

175. Id. at 598-99.

176. See supra Part I.C. 
Lee demonstrates that the standing problem does not result only from understanding constitutional guarantees in expressive terms. In Lee we have an expressive violation and no standing problem. Thus, some other feature must also be present to create a problem. Consider the Establishment Clause cases in which we do find very broad standing adopted. There, the offending state action is to display an allegedly religious symbol in a public space. ${ }^{177}$ The reason this type of case creates a standing problem is that the state action isn't directed at anyone in particular. The crèche or menorah is there for everyone to see. Similarly, in the re-districting context, the state action of drawing districts is not directed at anyone in particular. As Issacharoff and Karlan point out, "[t]o include a voter in one district is necessarily to exclude him from all other districts; it cannot be the case that only voters in one particular district have 'personally been subjected to a racial classification."'178 Because the locus of the constitutional wrong in expressive cases is not injury, we look to some other particularized effect of the state action for standing purposes. In some cases, like Lee, we find it; in others, like Lynch, we do not.

So perhaps we ought not worry so much about standing after all. In most Equal Protection cases, standing will stand alone because the state action will not affect all equally. In those rare instances where the state action does affect all equally, a commitment to the right understanding of the constitutional guarantee must make us accept the inconvenience of a broad standing requirement. ${ }^{179}$

\section{THE DOCTRINE APPLIED}

This section provides the reader with a more concrete and detailed sense of the contours of the proposed theory by looking at how it would be applied. I have chosen to consider three types of discrimination that are not often analyzed together: veterans' preferences, discrimination on the basis of sexual orientation, and distinctions based on non-citizen status. By discussing these examples, it will be possible to address several

177. See Allegheny, 492 U.S. at 578-89; Lynch, 465 U.S. at 671-72.

178. Issacharoff \& Karlan, supra note 168, at 2288 (quoting United States v. Hays, 515 U.S. 737, 745 (1995)).

179. Of course even in the redistricting cases, there will be some limitation on standing. Only those voters in the state have standing, because they are the only ones who could have been assigned to the districts subject to the plan. 
questions that may be raised about the expressive conception of Equal Protection. 180

Does the Equal Protection Clause prohibit the expression of special appreciation for some people, or will that run afoul of the mandate of equal concern and respect? In order to address this question, I consider the case of veterans' preferences below. Second, would the theory presented in this Article invalidate laws that express condemnation for persons or behaviors, even where arguably justified? Here, examples include most criminal laws, laws against polygamy, so-called "Megan's laws," and, of course, Romer $v$. Evans. ${ }^{181}$ Because Romer itself has generated so much academic commentary as a decision in search of a rationale, I address this question by looking at that case and the commentary it has engendered. Third, how broad is the protection I describe? After all, the Equal Protection Clause commands that "[n]o State shall ... deny to any person within its jurisdiction the equal protection of the laws."182 Does this mean that states may not enact laws that express that non-citizens, even those illegally present within the state's borders, are of less concern to the state than U.S. citizens? This question challenges whether the interpretation of Equal Protection offered in this Article can be squared with a conception of the nation state as morally significant. The sections below consider each of these questions.

\section{A. VETERANS' PREFERENCES}

Many federal and state laws give veterans preference in hiring and promotion decisions for civil service jobs. ${ }^{183}$ Generally, these laws provide that a specified number of points be added to the test scores of veterans, thereby allowing lower scoring veterans to be hired ahead of higher scoring nonveterans. ${ }^{184}$ These preference programs are clear instances of

180. In discussing the ideas presented in this Article with others, I found that similar questions were asked repeatedly.

181. 517 U.S. 620 (1996).

182. U.S. CONST. amend. XIV, $\S 1$.

183. E.g., 38 U.S.C. $\S 4214$ (1994) (noting in subsection (a)(1) that the United States "has an obligation to assist veterans of the Armed Forces in readjusting to civilian life" and advancing the policy of "promot[ing] the maximum of employment and job advancement opportunities [for qualified veterans] within the Federal Government"); see infra note 184 (giving examples of state laws and constitutions establishing veterans' hiring preferences).

184. E.g., Colo. CONST. art. XII, $\S 15$ (authorizing the addition of five 
discrimination-using the term "discrimination" in the nonpejorative sense. The law targets the veteran qua veteran and treats him differently than the civilian. ${ }^{185}$

Most striking about the cases that challenge these laws is that they fail to address the fundamental question: may a state privilege veterans qua veterans consistent with the requirements of Equal Protection? The defining constitutional case in this area, Personnel Administrator v. Feeney, ${ }^{186}$ which has been taken as the authoritative statement that veterans' preferences are constitutional, actually addressed the question whether such a preference unconstitutionally discriminates on the basis of sex. The Court held that "[t]he distinction made by ch. $31, \S 23$, is, as it seems to be, quite simply between veterans and nonveterans, not between men and women."187 The Court upheld the preference on this ground. While the Court recognized that a status-based distinction was in play, noting that "this case is unusual in that it involves a law that by design is not neutral," which "overtly prefers veterans as such,"188 the Court did not address whether this status distinction itself was permissible because "the District Court found, and the appellee has not disputed, that this legislative choice was legitimate."189

Absent from the case law is an analysis of whether and on what basis the "headstart" for a "specifically described" and "particularly deserving" group described in Feeney190 is permissible. So far, this gap in the case law has evaded notice. In the 1983 case Regan $v$. Taxation with Representation, ${ }^{191}$ the Court upheld a tax provision giving favorable treatment to veterans groups engaged in lobbying while denying such favor to other charitable groups that lobby on the basis that "[o]ur

points to civil service examinations of veterans achieving passing scores); ARIZ. REV. STAT. § 38-492 (1999) (same); ARK. CODE ANN. § 21-3-302 (Michie 1996) (same); CONN. GEN. STAT. ANN. § 7-415 (West 1999) (same).

185. In the terms I developed in my previous work, these veterans' preferences are instances of "non-proxy" discrimination because the policies do not target veterans in order to reach a group of people with a different trait that is correlated with veteran status (as is the case in proxy-discrimination). Rather the laws target veterans in order to privilege veterans themselves. See Hellman, supra note 52, at 318-19.

186. 442 U.S. 256 (1979).

187. Id. at 275.

188. Id. at 277 .

189. Id.

190. Id.

191. 461 U.S. 540 (1983). 
country has a longstanding policy of compensating veterans for their past contributions by providing them with numerous advantages."192 In the Court's view, review of this "longstanding" status discrimination was unnecessary because, quoting Feeney, "[t]his policy has 'always been deemed to be legitimate."'193 Thus, although Feeney itself did not address whether the laws that privilege veterans qua veterans are in fact permissible, Feeney now stands for that proposition.

The theory advanced in this Article requires that we first determine what the veterans' preference expresses. Second, we decide whether that meaning comports with the principle of equal concern. Using the language of the case law as a guide, it appears that the meaning of veterans' preferences to judges is an expression of honor, gratitude, and compensation. As the Court explains in Feeney, "[t]he veterans' hiring preference in Massachusetts, as in other jurisdictions, has traditionally been justified as a measure designed to reward veterans for the sacrifice of military service."194 The Court in Regan emphasizes the hardships of military service that warrant "compensating veterans for their past contributions." 195 Not only do the hardships of military service, particularly wartime service, require honor and compensation, in the words of the Pennsylvania Supreme Court, "[i]t is the greatest service a citizen can perform, and it comes with ill grace for those of us not in such wars to deny them just consideration."196

While judges' readings of what laws express are by no means authoritative, here they seem to be largely accurate. The laws express the country's appreciation for the sacrifices of military service. They mark the fact that this contribution to the country is different from the contributions to the economy and communal life that civilians make. By enacting the preference, the country expresses gratitude to the veteran for this contribution. ${ }^{197}$

192. Id. at 551.

193. Id. (quoting Feeney, 442 U.S. at 279 n.25).

194. 442 U.S. at 265.

195. 461 U.S. at 551.

196. Commonwealth ex rel. Graham v. Schmid, 3 A.2d 701, 704 (Pa. 1939).

197. In claiming that the veterans' preference expresses honor and gratitude toward veterans for their unique contribution to our community, I do not mean to suggest that it rewards an unmerited honor. On this view, service to one's country deserves our appreciation. However, this understanding of the meaning of these laws ought not to be confused with the claim that the veterans must be paid back-as it were-for the years of job experience that 
At first blush this meaning surely seems consistent with the requirements of equal concern. This is a message of honor, not of denigration. Therefore, we would conclude that veterans' preferences do not offend Equal Protection. But perhaps this is too quick. The preference expresses special regard for veterans. Perhaps by exhibiting heightened concern, the preference violates the mandate of equal concern. In other words, does the principle of equal concern forbid a classification that picks out a class of people for honor? Feeney cites an early Massachusetts case that apparently concluded that the answer to this question is yes; the case invalidated a prior veterans' preference law on the grounds that it was in conflict with the state constitution's provision forbidding "hereditary titles." 198

Before addressing the question whether the expression of special concern violates the principle of equal concern, it is important to note that this meaning is not merely the functional converse of a law whose meaning denigrates. Of course the concrete effect of the two laws may be the same: a veterans' preference will make it substantially more difficult for non-veterans to secure civil service jobs. However, the message of exclusion or lack of regard is, nonetheless, always a more direct and clear conflict with the commitment to equal concern.

Notwithstanding this important difference, status distinctions that honor one particular group may be problematic. Whether it is possible to revere one group without violating the principle of equal concern implicates a deep and

they lack due to their absence from the civilian job market. On this view, which has been advanced in some cases, the veterans are less qualified than civilian applicants because their service deprived them of the opportunity to gain either education or experience that other more qualified candidates possess. See, e.g., Johnson v. Robinson, 415 U.S. 361, 380 (1974). Interestingly, other cases examine the claim that the veterans' preference is legitimate because veteran status is a good proxy for job ability. See, e.g., Markel v. McIndoe, 59 F.3d 463, 470 (3d Cir. 1995) (rejecting the veterans' preference as a good proxy for job ability); Schmid, 3 A.2d at 704 (stating that veterans should be given credit for the experience and discipline gained through serving in the military). In other words, the experience of military service makes the job applicant especially well-qualified for the civil service job. These contradictory explanations belie the value of treating the veterans' preference as a proxy at all. The best understanding of these laws sees the preference not as a proxy at all, but instead as a means of selecting veterans qua veterans because we, as a community, wish to honor veterans for their service.

198. 442 U.S. at 266 (citing Brown v. Russell, 43 N.E. 1005, 1008 (Mass. 1896)). 
important debate between what may be loosely called multiculturalism and cosmopolitanism. The following discussion will not resolve the question that this distinction provokes, but will clarify issues in a way that advances our understanding.

The hope of the multiculturalist is that it is possible for members of different cultures to take pride in their own culture while not violating the principle of equal concern. The multiculturalist believes that through valuing one particular cultural tradition, one gains a means of valuing the traditions of others. The cosmopolite, in contrast, fears that the step from cultural pride to cultural superiority is far too short and distrusts our ability to cherish our own traditions without thereby finding them superior to those of others. Cosmopolitanism emphasizes our common humanity and shared values rather than our cultural differences.

Each view is motivated by a particular vision of the good (cultural diversity, common humanity). But perhaps more importantly, each is motivated by a distinct fear. The multiculturalist fears a loss of richness, difference, and depth. She fears absorption into the dominant culture masquerading as a neutral non-ethnic middle ground. The cosmopolite fears the disintegration of our ability to jointly pursue a common good, and the cosmopolite fears violence.

Whether one is more drawn to the multicultural or the cosmopolitan vision may have much to do with one's faith in humanity, one's fear of violence, and the value that one's particular cultural tradition has in one's own life. In an ideal form, multiculturalism may be preferable-cultural richness without divisiveness. But if real communities will always fall short of ideal visions, we will likely continue to disagree about whether the blandness of the non-ideal cosmopolitanism or the distrust of the non-ideal multiculturalism is the more pressing and important danger. The question whether we can honor one group while maintaining an equal regard for others is the challenge of multiculturalism. Since veterans' preferences express reverence for veterans, they implicate the issues of this debate.

However, veterans may be a particularly easy instance of the general question: can one revere one group without violating the principle of equal concern? Because the preference honors veterans for their conduct, it is a status-based distinction that has its roots in conduct. When we honor people for what they 
do, so long as the opportunity to do the honored act is open to all on a fair basis, the discrimination is less problematic. In fact it is consistent with the ideals of multiculturalism and cosmopolitanism at the same time. We revere a particular way of life, one that includes military service, while allowing anyone that wishes the opportunity to pursue that way of life.

Of course fair opportunity to enter the military and thereby gain veteran status is key to the above resolution. In this regard the challenge of Feeney makes sense. Helen Feeney was excluded from advancement within the Massachusetts civil service because less qualified veterans repeatedly were chosen for jobs over her. ${ }^{199}$ Feeney framed her challenge as sex discrimination. According to this theory, she must argue that the legislature adopting the veterans' preference knew that the preference would disproportionately favor men. One can therefore infer that the legislature intended to restrict the employment opportunities of women. ${ }^{200}$ As the Court understands it, Feeney's claim is grounded on the "presumption, common to the criminal and civil law, that a person intends the natural and foreseeable consequences of his voluntary action."201

But surely it is a stretch to argue that the legislature enacted the veterans' preference in order to bar women from civil service jobs. There may well be a problem with Feeney's exclusion, but it doesn't seem to derive from the legislature's invidious intent to keep women out of the civil service. No doubt Feeney frames her claim in this way because the doctrine requires impermissible purpose for an Equal Protection violation. Here, we see the doctrine working to contort claims in counterintuitive ways. The veterans' preference in Feeney is not problematic because the legislature intended to discriminate on the basis of sex. Rather, the preference is problematic because it expresses honor for a way of life that was not open to both sexes.

\section{B. ROMER V. EVANS}

Next we consider whether the theory presented in this Article would invalidate laws that express disapproval for persons or conduct for reasons that purport to be just.

199. See id. at 264 .

200. See id. at 276.

201. Id. at 278. 
Examples include garden variety criminal laws which outlaw conduct that harms others, laws against polygamy and homosexuality, which outlaw consensual activity for moral reasons, and statutes like "Megan's law,"202 which require that the names of ex-convicts of sex crimes be made public. The question that is posed by each of these examples is whether or not the mandate of equal concern prohibits the state from expressing moral disapproval of the conduct of some persons. This question may be addressed using the literature spawned by the decision in Romer $v$. Evans. ${ }^{203}$ That case's importance dictates that an Equal Protection theory would be flawed if it could not adequately analyze and answer the question presented by the facts of that case.

In Romer, the Court struck down an amendment to Colorado's constitution ${ }^{204}$ passed by referendum that prohibited cities and towns within the state from enacting legislation that would protect gay men and lesbians from discrimination on the basis of sexual orientation or conduct. ${ }^{205}$ The analysis of whether Colorado's Amendment 2 violates Equal Protection proved difficult for the Court because, as Justice Kennedy explained, "Amendment 2 confounds this normal process of judicial review." 206 This difficulty derives from the fact that Amendment 2 is an instance of status rather than proxy discrimination. ${ }^{207}$ Gay men and lesbians are identified within the amendment in order to reach gay men and lesbians themselves rather than as a proxy for a different set of people. Justice Kennedy's opinion for the Court expressly recognizes this: Amendment 2 is "a classification of persons undertaken

202. See infra note 261 .

203. 517 U.S. 620 (1996).

204. Amendment 2 reads:

"No Protected Status on Homosexual, Lesbian, or Bisexual Orientation. Neither the State of Colorado, through any of its branches or departments, nor any of its agencies, political subdivisions, municipalities or school districts, shall enact, adopt, or enforce any statute, regulation, ordinance or policy whereby homosexual, lesbian or bisexual orientation, conduct, practices or relationships shall constitute or otherwise be the basis of or entitle any person or class of persons to have or claim any minority status, quota, preference, protected status or claim of discrimination."

Id. at 624 (quoting CoLO. CONST. art. II, $\S 30 \mathrm{~b}$ ).

205. Id. at $635-36$.

206. Id. at 633 .

207. See Hellman, supra note 52, at 336-38. 
for its own sake."208 Because current doctrine is geared primarily to handle cases of proxy discrimination, the Court was ill-equipped to address the question presented by Colorado's adoption of Amendment 2.

Because current doctrine is so clearly inadequate to address the issue presented in Romer, the case has generated significant academic commentary that attempts to provide an alternate account of its grounds. ${ }^{209}$ For example, for Akil Amar, Amendment 2 violates the Constitution's prohibition on Bills of Attainder, 210 and for Daniel Farber and Suzanna Sherry, the Amendment conflicts with something they term the "Pariah Principle"211 - a principle which, in their view, forbids government from making any group or individual pariahs. ${ }^{212}$ These alternate theories seem to be reaching for something akin in many respects to the view offered here: that status discrimination is impermissible when it conflicts with the principle of equal concern.

\section{Amar: Attainder}

According to Akil Amar, the Attainder Clause ${ }^{213}$ prohibits government from identifying and disadvantaging a defined class of people.214 For Amar, the distinction between status and conduct is extremely important: "Government may pass laws classifying conduct-if you do act A, you suffer consequence B-but it may not create classes among citizens on

208. Romer, 517 U.S. at 635.

209. E.g., Akhil Amar, Attainder and Amendment 2: Romer's Rightness, 95 Mich. L. REV. 203 (1996); Daniel Farber \& Suzanna Sherry, The Pariah Principle, 13 CONST. COMMENT. 257 (1996); Roderick M. Hills, Jr., Is Amendment 2 Really a Bill of Attainder? Some Questions About Professor Amar's Analysis of Romer, 95 MICH. L. REV. 236 (1996); Koppelman, supra note 130; Louis Michael Seidman, Romer's Radicalism: The Unexpected Revival of Warren Court Activism, 1996 SUP. CT. REV. 67; Cass R. Sunstein, The Supreme Court, 1995 Term-Foreword: Leaving Things Undecided, 110 HARV. L. REV. 4 (1996).

210. Amar, supra note 209, at 208-21.

211. Farber \& Sherry, supra note 209.

212. Id. at 269 (arguing that in "equal protection cases, bill of attainder cases, and even cruel and unusual punishment cases" the Court recognizes "[t]he principle ... that the government cannot brand any group as unworthy to participate in civil society").

213. Article I, Section 9 of the United States Constitution provides, inter alia, "[n]o bill of attainder or ex post facto law shall be passed."

214. Amar, supra note 209, at 226. 
the basis of who they are rather than what they do."215 This claim is surely too broad. For example, as Roderick Hills points out in his insightful critique of Amar's theory, ${ }^{216}$ some conductbased distinctions are attaints (laws that target people who supported the Confederacy during the Civil War or those who were members of the Communist Party) ${ }^{217}$ and some statusbased distinctions are not attaints (age classifications). ${ }^{218}$

Hills's interpretation of the attainder clause is more persuasive. For Hills the Clause prohibits legislative classifications that target and disadvantage closed classes of people. ${ }^{219}$ For example, laws that targeted Confederacy supporters were attaints (though the class was defined by past conduct) because at the time the law was enacted, no one could enter or exit the group. ${ }^{20}$ For Hills, the reason for this prohibition derives from an attempt to balance the moral imperative to enact general laws (to insure that no one is singled out for mistreatment) with the desire to accommodate the need to pass laws aimed at particular problems. ${ }^{221}$ Laws must classify in order to achieve many legitimate purposes. Amar tries to mediate between these twin goals by drawing a distinction between conduct-based classes and status-based classes. As the examples above demonstrate, that resolution will not work. Hills's mediation defines a much narrower scope for the attainder principle. It prohibits legislation that disadvantages closed classes only, because here the "veil of ignorance" that for Hills "should ... accompany legislation" is too thin..$^{22}$

This reading of the Attainder Clause also makes sense if we expect that the Equal Protection Clause adds something to it. The prohibition on bills of attainder proscribes an important but narrow form of unequal treatment: the disavantaging of a named, closed class of people. Amar is probably right to remind us of the Attainder Clause in the context of Romer because the

215. Id. at 222.

216. See Hills, supra note 209 , at 246.

217. Id. at 247 (citing Ex parte Garland, 71 U.S. (4 Wall.) 333 (1866); Cummings v. Missouri, 71 U.S. (4 Wall.) 277 (1866); United States v. Brown, 381 U.S. 437 (1965)).

218. $I d$.

219. Id. at 240 .

220. Id. at 247 .

221. Id. at 239-40.

222. Id. at 241 . 
two clauses (Equal Protection and Attainder) spring from the same moral foundation. Attainder, the earlier constitutional prohibition, instructs that disadvantaging a particular individual or known, specific group, violates the government's moral obligation to treat everyone with equal concern. Attainder itself is a form of unequal protection. However, the prohibition on attainders will not explain the Romer result, if Hills's critique of Amar is right, because Amendment 2 did not target a named, closed class of people for disadvantage.

\section{Farber and Sherry: The Pariah Principle}

Daniel Farber and Suzanna Sherry's account of Romer's wrongness ${ }^{223}$ is more promising. For Farber and Sherry, something they term "the pariah principle"224 underlies several constitutional clauses including both the Equal Protection and the Attainder clauses. In their view, this principle "forbids the government from designating any social group as untouchable."225 To be a pariah "is to be shunned and isolated, to be treated as if one had a loathsome and contagious disease."226 Since, in their view, Colorado's Amendment 2 amounted to state-sponsored shunning, it ran afoul of this pariah principle. ${ }^{227}$ This account has two flaws. First, Farber and Sherry understand their principle as tapping a prohibition that also animates other constitutional provisions. If so, why add this new principle? Second, in their view the problem with making some people pariahs lies in the effect of so doing. In locating the constitutional wrong in the effect of these laws, Farber and Sherry's view is open to the same counter-examples as the stigma conception-instances where our intuitions tell us there is an important wrong yet the victims suffer no immediate harm. 228

In Farber and Sherry's terms, state action violates the pariah principle when it "brands [members of a group] as inferior and encourages others to ostracize them."229 This passage makes clear that the pariah principle shares a moral

223. See Farber \& Sherry, supra note 209, at 262-64.

224. Id. at 267-68.

225. Id. at 258.

226. Id. at 266.

227. See id. at 281.

228. The hypothetical case of segregating by race in care facilities for patients in a persistent vegetative state is a good example. See supra Part I.C.

229. Farber \& Sherry, supra note 209, at 267. 
basis with the conception of Equal Protection endorsed in this Article. A law must not "brand" a group of people as inferior. Farber and Sherry borrow this term from Strauder $v$. West Virginia ${ }^{230}$ citing the Court's language in striking down the prohibition on blacks sitting on juries as "practically a brand upon them."231 Of course, Farber and Sherry use the branding term metaphorically. A law brands people as inferior in those cases where it expresses unequal concern. Although Farber and Sherry do not explain their view in these terms, their conception of a pariah rests, in part, on the view that certain governmental action is forbidden because of its meaning.

This Article endorses Farber and Sherry's view insofar as their account of the pariah principle implicitly supports the view that the expressive character of law is at the root of equal protection. However, as Farber and Sherry explain and defend their view, it takes a different form. First, Farber and Sherry's pariah principle forbids only those governmental actions whose meaning brands the outcast group as pariahs or untouchables. In their view, the Equal Protection Clause, by contrast, may well proscribe more. Therefore the pariah principle merely sets out a floor.

But what is the advantage of this conception? If the laws prohibited by the pariah principle would also be forbidden by other clauses including Equal Protection and Attainder, what is gained by postulating this new principle? A preference for explanatory parsimony alone argues against it. In fact, as the principle sets out a floor, those laws that violate the pariah principle should be especially clear violations of other constitutional prohibitions. Therefore, the concept of a pariah is unnecessary. Moreover, there is a risk in postulating this new principle. Judges employing the theory may become confused and take the floor for the ceiling. If the idea of a pariah becomes enshrined as the paradigm Equal Protection violation, laws with less egregious meanings that still violate the principle of equal concern may mistakenly be held constitutionally permissible.

The second problem with Farber and Sherry's view is that it misconceives the locus of the constitutional violation. According to Farber and Sherry, a law violates the pariah principle when, in branding a group as untouchable, it limits

230. 100 U.S. 303 (1879).

231. Id. at 308; Farber \& Sherry, supra note 209, at 267. 
the "victims' right to participate in civil society."232 The constitutional wrong inheres in the effect that the law has on meaningful civic participation by those it targets. Farber and Sherry distinguish this position from what they term the "stigma" conception of Equal Protection. ${ }^{233}$ That view, which they attribute to Charles Lawrence and Kenneth Karst, ${ }^{234}$ locates the constitutional violation in the psychological harm suffered by those affected. ${ }^{235}$ But because for Farber and Sherry, the effect of the law in question (i.e., whether the law effectively limits civic participation) is also the source of the constitutional wrong, it too falls prey to the same critique.

This Article previously argued that the stigma conception of Equal Protection is inadequate because it fails to account for the case where a state segregates day care centers for infants. ${ }^{236}$ Such segregation would violate Equal Protection notwithstanding the fact that the babies suffer no psychological harm. Similarly, Farber and Sherry's civic participation conception fails for the same reasons. The rights of the babies to participate in civil society are not affected, or only so in the most attenuated sense. The connection between this wrong (the segregation of day care centers) and meaningful civic participation is remote and speculative. This example makes clear that any theory that attempts to ground the constitutional violation of unequal protection in the effect of the law on those whom it targets will be inadequate. There will be some class of persons (e.g. infants, the severely mentally disabled) who suffer no identifiable harm. Because our intuitions remain strong that these cases also violate important constitutional guarantees, they demonstrate that the constitutional wrong must inhere in the expressive dimension of the governmental action.

\section{Koppelman: Objective Intent}

The last of the many articles reacting to the Court's decision in Romer considered here is Andrew Koppelman's Romer v. Evans and Invidious Intent ${ }^{237}$ in which he is one of

232. Farber \& Sherry, supra note 209, at 272.

233. See id. at 272.

234. See id. at 271-72 (citing Lawrence, supra note 12, at 317; KARST, supra note 2 , at 3 ).

235. I too reject this view. See supra Part II.A.

236. See discussion supra Part I.C.

237. Koppelman, supra note 130. 
the lone voices to argue that current Equal Protection doctrine accommodates the Romer result. Koppelman reaches this conclusion by reading current doctrine as prohibiting laws whose objective intent is invidious. ${ }^{238}$ By focusing on objective intent, Koppelman attempts to salvage current doctrine. But by focusing on objective rather than subjective intent, Koppelman concedes that it is the meaning of governmental action that matters. However, Koppelman defends the use of objective intent as important because it is the best available evidence of subjective intent. Thus, while our views may be superficially similar, they are justified on very different grounds.

Koppelman understands the Court's opinion in Romer as protecting process-based values. ${ }^{239}$ The subjective intent of legislators matter, then, because laws enacted for impermissible reasons constitute the kind of process-based defect that must be corrected. As Koppelman and others have described the problem: "garbage in, garbage out." 40 But Koppelman also recognizes that it is often difficult for a court, or anyone really, to know what the subjective intentions of the law's supporters really are. ${ }^{241}$ Moreover, these obstacles are compounded in laws enacted by referendum. As Koppelman explains, "[t]he problems of discerning the subjective intent of lawmakers obviously become insuperable when one confronts a lawmaking body composed of hundreds of thousands, or even millions, of voters."242 Koppelman thus turns to objective intent.

But what exactly is objective intent? For Koppelman, objective intent appears to be equivalent to meaning or the expressive dimension of law. Comparing Romer with Loving $v$. Virginia, ${ }^{243}$ Koppelman explains that the Court rightly struck down the law at issue in each case because "the classifications in question [in each] were ones that were widely understood to separate those citizens who were fully human from the

238. Koppelman thus agrees with Baker's descriptive claim that objective intent is already used in assessing violations of Equal Protection.

239. See Koppelman, supra note 130, at 93.

240. Id. at 101 (citing JOHN RAWLS, POLITICAL LIBERALISM 430-31 (2d ed. 1996)).

241. See id. at 107.

242. Id. at 109 .

243. 388 U.S. 1 (1967). 
untermenschen."244 Thus, Koppelman's objective intent focuses on how the use of classification will be interpreted; this is its expressive character.

But Koppelman has a problem arguing for the doctrinal importance of meaning or the expressive character of laws while at the same time maintaining the normative importance of subjective intent. If objective intent matters because it is evidence of subjective intent, then why not pay attention to other evidence of subjective intent when it is available? Yet Koppelman wants to reject such evidence: "A well-crafted set of implementing rules, however, will push subjective motive so far outside the scope of inquiry ... that evidence of motive, in fact, will become entirely irrelevant to the adjudication of the law's constitutionality, perhaps to the point of being inadmissible in court."245 This is not merely a "paradox" as Koppelman concedes, ${ }^{246}$ but rather an insurmountable inconsistency in the view that Equal Protection prohibits invidious intent. Either subjective intent is what really matters, and then objective intent must be seen as simply one kind of evidence of it; or subjective intent is irrelevant, and objective intent matters independently and for its own sake.

In sum, Koppelman's interpretation of Romer's rightness is to be commended for drawing attention, even if inadvertently, to the importance of objective meaning. Insofar as he believes that the pervasive animus directed at gay men and lesbians in our society today is relevant to the best understanding of what Amendment 2 expresses, I agree with Koppelman's account. Where we part company, however, is with regard to his ongoing attachment to subjective intent as constitutionally and morally significant. This failing, which makes his view ultimately inconsistent, is likely the result of his attempt to make the Romer opinion consonant with current doctrine. Rather, the opinion's inadequacy demonstrates the inability of the current doctrine to handle the issue the case presents-thus the plethora of law review articles trying to make sense of $i^{247}$ and the rightness of its result shows the need to re-conceive the doctrine.

244. Koppelman, supra note 130, at 133 (emphasis added).

245. Id. at 136.

246. See id.

247. See supra note 209. 
4. The Expressive Conception of Equal Protection as Applied to Romer

It is far easier to criticize, to find holes or defects in another's theory, then to advance a convincing account oneself. So while the above discussion shows the problems with each of the grounds offered for the Court's holding in Romer, the real challenge is to demonstrate that the expressive theory of Equal Protection proposed in this Article provides a more convincing account of the Romer result.

In order to assess whether Colorado's Amendment 2 violates the Equal Protection clause we must ask two questions. First, what is the pubic meaning of the amendment or what does the amendment express? Second, does that meaning conflict with the principle that the government must treat all with equal concern? The first is an interpretive question to which I can give only my best assessment. Therefore, this part of my analysis is severable from the rest of the theory. One can accept the argument that the expressive character of law determines whether it violates Equal Protection and yet disagree with my reading of the meaning of any particular statute or policy. As explained earlier, judges must simply do the best they can in assessing what a given law expresses, while listening closely to the viewpoints of others. ${ }^{248}$

So, with that caveat, let me say that I think the best interpretation of the meaning of Amendment 2 is as the expression of denigration of gays and lesbians. The Amendment expresses "animosity toward the class of persons affected."249 Interestingly, Justice Scalia's dissenting opinion addresses the question of the Amendment's expressive character directly. In countering the Court's assertion that the law is "born of animosity," Justice Scalia argued:

Of course it is our moral heritage that one should not hate any human being or class of human beings. But I had thought that one could consider certain conduct reprehensible-murder, for example, or polygamy, or cruelty to animals-and could exhibit even "animus"

248. See supra Part II.C.

249. Romer v. Evans, 517 U.S. 620, 634 (1996). Justice Kennedy's opinion for the Court describes the Amendment as "born of" this animosity, id., thereby indicating that subjective intent is the constitutionally determinative factor. In my view, the Amendment's social meaning is also animosity toward gay men and lesbians. 
toward such conduct. Surely that is the only sort of "animus" at issue here: moral disapproval of homosexual conduct..$^{250}$

In other words, Scalia reads the law as the expression of moral disapproval for homosexuality only.

Remember, the assessment of expressive character takes the motives of those who enact the legislation (or in this case voted for the referendum) as only one data point in the analysis. It is likely that some of those who voted for Amendment 2 had each of the above intentions in mind. But an analysis of the expressive dimension of law must also consider other aspects of society and culture to determine the best reading of the law's meaning. As this Article's main aim is to explain and defend an expressive theory of Equal Protection rather than to defend a particular application of the theory, I will not delve too deeply into the interpretive question here. Briefly, I point out only that the prevalence of violence against homosexuals in our society, which Andrew Koppelman describes quite effectively in his article, ${ }^{251}$ makes it more plausible to read the Amendment as an expression of hatred for a class of human beings, as denigrating the worth of gay men and lesbians as people.

However, Scalia's defense of Romer does raise a provocative question. If our culture were different, such that it were plausible to interpret Amendment 2 as the expression of moral disapproval of homosexuality without animus toward people, would such a meaning comport with the mandate of equal concern? Farber and Sherry answer this question in the negative in asserting that their pariah principle forbids all shunning. ${ }^{252}$ They do so because they imagine that all shunning is accompanied by animus or denigration. ${ }^{253}$

But Justice Scalia presses just this question. He does so by asking how a state may treat polygamists. ${ }^{254}$ To make this question more insistent, let us consider whether the Equal Protection Clause forbids state expression of an analogous moral disapproval of smokers. As a means of expressing moral

250. Id. at 644 (Scalia, J., dissenting).

251. For a detailed catalogue of such violence, see Koppelman, supra note 130, at 123-26.

252. Farber \& Sherry, supra note 209, at 266.

253. According to Farber and Sherry, to shun is to treat someone as "untouchable," as if he had a "loathsome and contagious disease. The message is that outcasts are not merely inferior; they are not fully human and contact with them is dangerous and degrading." Id.

254. See Romer, 517 U.S. at $648-50$ (Scalia, J., dissenting). 
disapproval for the unhealthy activity of smoking, suppose Colorado were to adopt an Amendment that forbade municipalities from providing anti-discrimination protection for smokers. In essence, the effect of such an ordinance is to permit discrimination against smokers on that basis. For example, if you are denied employment or housing because you smoke, you have no recourse. Of course, if smokers are discriminated against on other grounds, race or sex for example, they retain the same protections as non-smokers-a point that was made repeatedly in defense of Amendment 2.255 I use the example of smokers because it is surely plausible that a smoker's Amendment 2 would express disapproval of smoking without animus toward smokers as people. Hate the "sin"; love the sinner.

John Finnis, a Christian legal philosopher, makes the most forceful argument for the permissibility of laws outlawing homosexual conduct on these grounds. ${ }^{256}$ As he explains,

[such legislation] may manifest, not contempt, but rather a sense of the equal worth and human dignity of those people whose conduct is outlawed precisely on the ground that it expresses a serious misconception of, and actually degrades, human worth and dignity, and thus degrades their own personal worth and dignity, along with that of others who may be induced to share or emulate their degradation..$^{257}$

While Finnis himself does not favor legislation outlawing homosexual conduct because he values the importance of individual moral choice, he does support legislation that discourages homosexuality or discriminates on the basis of homosexual orientation for the reasons articulated above. ${ }^{258}$ But can he make the same claim with regard to Amendment 2?

Amendment 2 and my hypothetical amendment forbidding discrimination protection for smokers are both forms of shunning. Interpreted in their best light, each expresses that because we respect the equal worth of the homosexual or smoker, society shuns this person in order to induce a change

255. See id. at 644 (Scalia, J., dissenting).

256. See J.M. Finnis, Legal Enforcement of “Duties to Oneself”: Kant v. Neo-Kantians, 87 CoLUM. L. REV. 433, 437 (1987).

257. Id. at 437. In his article, Koppelman explicitly leaves open the question whether legislation animated by this view would be permissible since he finds that the climate of hatred of homosexuals makes this interpretation implausible. See Koppelman, supra note 130, at 116.

258. John M. Finnis, Law, Morality, and "Sexual Orientation," 9 NOTRE DAME J.L. ETHICS \& PUB. POL'Y 11, 35 (1995). 
in behavior. To shun a person cuts her off from the bonds of civil society; it is a sort of internal exile. These Amendments invite shunning in that they condone acts of private individuals who refuse to hire and rent or sell property, etc., to the persons identified. The Amendments would, as Farber and Sherry claim, make such persons pariahs, but not necessarily with the ill-will Farber and Sherry assume is always attendant. This is Finnis's point.

In answering Finnis's question whether shunning which is done with respect for the worth of the people shunned is consistent with the principle of equal concern, the fact of pluralism, which is emphasized earlier, ${ }^{259}$ is important. There is a plethora of views about what makes human life valuable. This diversity places some limitations on government. While the state may surely express views about what is good or valuable (think of anti-smoking campaigns or AIDS education), it may not go so far as to expel non-adherents from the conversation. When the government funds an anti-smoking campaign, it expresses the view that health is of greater value than the pleasure associated with smoking. The government endorses a particular conception of what a good life requires. This is permissible because the attempt to persuade itself acknowledges the equal worth of those with whom one disagrees. ${ }^{260}$

By contrast, shunning removes those shunned from contact and thus dialogue with others in the community. Shunning attempts to insulate adherents of the orthodox view from interaction with non-adherents. A law that condones shunning thus violates the requirement of equal concern because it expresses that certain people are properly excluded from conversation about what is of value. ${ }^{261}$

259. See supra Part II.C.

260. But see Lessig, supra note 10, at 1039 (arguing for limitations on the expressive function of government).

261. Laws that provide for registration of releases sex-offenders and community notification (so-called "Megan's laws") may have a similar social meaning. If so, these laws may be vulnerable on Equal Protection grounds. Under current doctrine, by contrast, commentators have generally found that an Equal Protection challenge to these laws would be weak. See, e.g., Carol L. Kunz, Toward Dispassionate, Effective Control of Sexual Offenders, 47 AM. U. L. REV. 453, 468-69 (1997).

Case law rejecting Equal Protection challenges to such laws demonstrates the limitations of the current doctrinal scheme. For example, in People $v$. Adams, 581 N.E.2d 637 (IIl. 1991), a challenge was brought to Illinois's Habitual Child Sex Offender Registration Act on Eighth Amendment, Due 
The above argument taps a similar vein as the First Amendment's prohibition on censorship. Censorship of ideas we find noxious conflicts with First Amendment values because it violates the dignity of the speaker and because the search for truth and understanding is aided by listening to all views. Just as we do not silence the Nazi who wants to march at Skokie, we ought not to allow any person or group to become internal exiles. Because Amendment 2 expresses that such banishment is permissible, it violates the mandate of equal concern.

In this respect, Justice Kennedy is right to identify the breadth of Amendment 2 as its constitutional infirmity. ${ }^{262}$ When governmental action expresses disapproval (even moral disapproval) for particular ways of life, it does not run afoul of Equal Protection. But when the government's expressive action condones shunning any group within our community, it so distances them from civic life that it fails to treat them with equal concern.

Much of the commentary on Romer addressed the question of whether Romer implicitly overruled Bowers v. Hardwick's ${ }^{263}$ holding that the state may criminalize homosexual sodomy without violating the Due Process clause. ${ }^{264}$ Without wading

Process, and Equal Protection grounds. Id. at 640. Because a sex-offender is not a member of a protected class and no fundamental right was involved, the challenger was forced to style his Equal Protection claim as unequal protection between sex-offenders like himself and pornographers and employers of child prostitutes. This way of framing the question is counter-intuitive. Surely the Equal Protection problem is not really about such under-inclusiveness. But the doctrine's emphasis on fit-on the rationality of classification-forces this strange posture. The weakness of current doctrine is exemplified by the ease with which the court disposes of this challenge, explaining that the use of children in pornography and prostitution is motivated by money and not sex and therefore that the distinction drawn by the statute is rational. See id. at 642.

262. See Romer v. Evans, 517 U.S. 620, 633 (1996) (noting that the Amendment "is at once too narrow and too broad" in that it "identifies persons by a single trait and then denies them protection across the board"). Kennedy recognizes that the effect of Amendment 2 will be a form of shunning from civil society. He describes its effect in this way: "[T]hese are protections against exclusion from an almost limitless number of transactions and endeavors that constitute ordinary civic life in a free society." Id. at 631.

263. 478 U.S. 186 (1986).

264. See Richard T. Ford, Law's Territory (A History of Jurisdiction), 97 MICH. L. REV. 843, 922-23 (1999) (discussing Romer's effect on Bowers and concluding that the former left the latter intact); Thomas Grey, Bowers v. Hardwick Diminished, 68 U. COLO. L. REv. 373, 374 (1997) (arguing that Romer did in fact overrule Bowers); Koppelman, supra note 130, at 137-46 (arguing that Romer does not implicitly overrule Bowers); Seidman, supra note 
too deeply into that debate, let me just say that overruling Bowers is not necessary to the Romer result. Surely the state may outlaw smoking without violating the fundamental rights of smokers. But it may not condone the shunning of smokers by inviting individuals to avoid all contact with them. To do so expresses the view that smokers ought not be participants in our ongoing conversations about what is of value. This denies them equal concern. ${ }^{265}$

\section{NON-CITIZENS}

There is a complex and interesting body of doctrine that governs when laws may distinguish between citizens and noncitizens without violating Equal Protection. I can treat that doctrine only briefly here. Nonetheless, I find it useful to explore the implications of my expressive theory of Equal Protection for non-citizens precisely because a somewhat discrete and contained body of doctrine has come to govern this field. Since I intend the theory proposed in this Article to handle Equal Protection cases regardless of the trait at issue, it makes sense to test its scope in a field that has so far generated a fairly insular body of doctrine.

The cases dealing with non-citizens are often understood as falling in one of two areas: immigration law and alienage law. ${ }^{266}$ Roughly speaking, immigration law deals with border issues: who may enter and who controls who may enter.

209 (arguing that Romer and Bowers are inconsistent).

265. On a related question, one might wonder whether a law like the Defense of Marriage Act, Pub. L. No. 104-199, 110 Stat. 2419 (1996) (codified in scattered sections of 1 U.S.C. and 28 U.S.C.), violates Equal Protection in that it surely expresses the view that heterosexual unions are more valuable than homosexual unions. As I mentioned earlier, it is plausible to hold this view without thereby impugning the moral worth of gay men and lesbians. See John Finnis, The Good of Marriage and the Morality of Sexual Relations: Some Philosophical and Historical Reflections, 42 AM. J. JURIS. 97, 126-34 (1997). A challenge to this law would thus raise the question how the state may express approval for some ways of life-and thereby implicitly disapproval for others-without violating the principle of equal concern. Following the approach outlined above, the state may express a viewpoint about what is of value so long as (1) it does not denigrate the moral worth of some individuals or groups (a point I am stipulating here), and (2) it does not work to exclude those whose values are impugned from contact with the community and thus from an opportunity to change the views of others. I am grateful to Amy Wax, Professor, University of Virginia School of Law, for raising this issue.

266. See, e.g., Linda S. Bosniak, Membership, Equality, and the Difference That Alienage Makes, 69 N.Y.U. L. REv. 1047, 1056-59 (1994). 
Alienage law, on the other hand, deals with issues inside our borders: what distinctions state and federal governments may make between citizens and non-citizens (legal and illegal). Some commentators have found this division so powerful that they see all Equal Protection questions dealing with aliens as, primarily, "jurisdictional" questions. ${ }^{267}$ Which world, immigration or alienage, does the law fall into? The legal standards in each are so different that this jurisdictional question is often dispositive.

In general, if a law deals with immigration, the "plenary power" doctrine governs, with the result that the Court will find the classification at issue permissible. ${ }^{268}$ Starkly put, Congress can do what it likes in controlling immigration. So, for example, if Congress wants to pass a law making communists deportable, that is fine, even though that would clearly violate the First Amendment if it were not preempted by the plenary power doctrine. ${ }^{269}$ As a corollary to this federal power, states may not pass laws distinguishing between citizens and aliens if such laws encroach on the federal immigration power. ${ }^{270}$ But federal laws dealing with immigration are almost always upheld. ${ }^{271}$

In contrast, when either the federal or state governments pass laws dealing with the status of aliens within the borders (excluding deportation issues), these laws are subject to strict scrutiny on the grounds that alienage is a suspect class. ${ }^{272}$ One

267. E.g., id. at 1056.

268. See, e.g., Fiallo v. Bell, 430 U.S. 787, 792 (1977).

269. See, e.g., Galvan v. Press, 347 U.S. 522, 532 (1954) (upholding a law allowing the deportation of aliens who join the Communist Party); Harisiades v. Shaughnessy, 342 U.S. 580, 592 (1951) (denying a First Amendment claim to communist aliens who were deported).

270. See Toll v. Moreno, 458 U.S. 1, 17 (1982) (striking down a Maryland law granting in-state tuition rates at the University of Maryland to domiciled citizens and immigrant aliens but denying it to non-immigrant aliens).

271. But see INS v. Chadha, 462 U.S. 919, 958-59 (1983) (striking down a law allowing a one-house veto of an executive branch decision to allow a deportable alien to remain in the United States on the grounds that such action is legislative and therefore requires passage by both houses and presentation to the President). Stephen Legomsky insightfully argues that Chadha demonstrates that the plenary power of Congress to control immigration is not in fact plenary, for "[i]n the same sentence in which the Court described the power as 'plenary,' it framed the issue as whether Congress's exercise of that power conforms to the Constitution." Stephen $\mathrm{H}$. Legomsky, Immigration Law and the Principle of Plenary Congressional Power, 1984 SUP. CT. REV. 255, 302.

272. See, e.g., Bernal v. Fainter, 467 U.S. 216, 227 (1984). 
might imagine therefore that these laws are almost always struck down; after all in other areas where strict scrutiny applies, race, for example, such scrutiny is said to be "strict in theory but fatal in fact." Instead, alienage law is organized around the concept of a political function. If the law discriminating against non-citizens restricts such persons from political functions, then it is permissible. For example, New York may allow only citizens to be police officers ${ }^{273}$ but may not allow only citizens to be civil servants. ${ }^{274}$ Lest you think this organizing concept sorts the cases in a rational way, note also that the Court has held that a probation officer 275 and a public school teacher 276 fulfill important political functions fairly entrusted only to citizens, but a lawyer does not. ${ }^{277}$

The two bodies of doctrine-immigration law and alienage law-can be seen as addressing the same question at root. Briefly, what is the normative significance of the nation state?278 In other words, does the requirement of nationbuilding justify the different treatment of the alien in the given context? So, for example, a defender of a truly plenary power over immigration can be understood to claim that nationhood requires an unfettered ability to control national borders. Similarly, a critic of the current political function doctrine can be understood to claim that nationhood does not require that public school teachers or probation officers be citizens.

This central question at the heart of these cases is addressed more directly by the Equal Protection theory proposed in this Article. When faced with a law that classifies on the basis of non-citizen status, the Court should ask the same two questions as in other Equal Protection cases. First, what is the law's meaning or what does it express? Second, is that meaning consistent with the mandate of equal concern?

273. Foley v. Connelie, 435 U.S. 291, 300 (1978).

274. Sugarman v. Dougall, 413 U.S. 634, 646 (1973).

275. Cabell v. Chavez-Salido, 454 U.S. 432 , 449 (1982) (upholding a California law requiring probation officers to be citizens).

276. Ambach v. Norwick, 441 U.S. 68, 80-81 (1979) (upholding a New York law requiring that public school teachers be citizens or have manifested an intention to apply for citizenship).

277. In re Griffiths, 413 U.S. 717, 729 (1973) (striking down a Connecticut law denying aliens admission to the state bar).

278. For a careful treatment of this question, see WILL KYMLICKA, MULTICULTURAL CITIZENSHIP: A LIBERAL THEORY OF MINORITY RIGHTS 10-33 (David Miller \& Alan Ryan eds., 1995). 
A critic might object that these are odd questions to govern whether discrimination against non-citizens is permissible since surely the government properly has less concern for noncitizens than for citizens. The key word here is "properly." As the issue was succinctly put by the Court in Mathews v. Diaz, where the Court upheld a federal law which favors citizens over aliens in the dispersal of welfare benefits, "[t]he fact that an Act of Congress treats aliens differently from citizens does not in itself imply that such disparate treatment is "invidious."'279 While the argument advanced in this Article is fundamentally in tension with Peter Westen's provocative assertion that the moral mandate of equality is empty, ${ }^{280}$ this is one place where his theory has some bite. The concept of equality cannot do all the work. In order to assess whether the deviation from equality between citizens and aliens is permissible, we must also understand the moral relevance of nationhood.

It is this question that ought to be front and center in each of the Equal Protection cases in this area. In the "political function" cases, the proposed shift would be less important than in the plenary power cases. For example, in assessing whether a state may limit employment as a public school teacher, notary, probation officer, lawyer, police officer, or civil servant to citizens, the Court should assess whether nationhood requires limiting such functions to members. While the particular lines the Court has drawn over time may not be well-justified, the basic aim of the inquiry is on the mark.

By contrast, the plenary power doctrine is ill-conceived. The fact that nationhood may support regulated borders does not imply that the criteria for entry and expulsion are not subject to the internal values of the nation itself. ${ }^{281}$ If nationhood has moral significance, that fact may limit the rights of outsiders to challenge the governing criteria for entry. But surely we insiders, members of the nation, may demand that these criteria meet our conception of our nation and its values.

279. 426 U.S. 67,80 (1976).

280. See Peter Westen, The Empty Idea of Equality, 95 HARV. L. REv. 537 (1982) (arguing that all questions of Equal Protection are reducible to questions regarding what substantive rights each person is entitled to and consequently that the moral imperative of equality is empty).

281. Stephen Legomsky has made a similar claim. See Legomsky, supra note 271 , at 270 . 
In this sense, Congress ought not be understood to have truly plenary power over immigration. Rather, that power should be judged by our constitutional values. This is not because the alien is entitled to rights under the Constitution when he is not even territorially present here, but rather because we, who are clearly entitled to the Constitution's protection, are entitled to have our borders controlled by the values that define our nation. It is this idea that the plaintiffs in the 1972 case Kleindienst $v$. Mandel ${ }^{282}$ seem to be reaching for. Unfortunately, current doctrine provides no way to frame this claim.

In Kleindienst, a Belgian journalist was denied an entry visa to the United States on the grounds that he was a communist. ${ }^{283}$ Both Mandel (the journalist) and the Stanford professors who invited him challenged the denial. Justice Blackmun, for the Court, denied the claims of both. ${ }^{284}$ Mandel, as a non-resident alien, had no right to enter. And, to the professors who asserted a First Amendment right to receive information, Blackmun asserted:

The case, therefore, comes down to the narrow issue whether the First Amendment confers upon the appellee professors, because they wish to hear, speak, and debate with Mandel in person, the ability to determine that Mandel should be permitted to enter the country or, in other words, to compel the Attorney General to allow Mandel's admission. ${ }^{285}$

This claim is weak on First Amendment grounds. Although the First Amendment includes the right to receive information, there are surely other ways to receive the information Mandel can provide: books, letters, telephone calls, etc.

The theory proposed in this Article offers a better way to capture what is troubling about the Kleindienst case. If we understand Equal Protection as essentially a protection against expressive action that conflicts with the principle of equal concern, then the denial of entry to Mandel because he is a communist violates this protection because it expresses the unequal worth of communists. The alien has no right of entry, but the professors have an Equal Protection claim based on the fact that the denial of entry to the alien-journalist expresses unequal regard for communists.

282. 408 U.S. 753 (1972).

283. Id. at 756-57.

284. Id. at 769-70.

285. Id. at 762 . 
It is important here not to confuse the basis of standing with the grounds of the constitutional claim. The fact that the professors want to hear Mandel and are denied that opportunity is the concrete interest that gives them standing to bring the Equal Protection claim, but it is not the basis of the claim itself. If the evil of unequal protection inheres in a noxious meaning, it is a harm that affects everyone regardless of whether or not we are the persons or group denigrated. The standing doctrine, which is justified on other grounds, demands that the persons bringing a claim have suffered a concrete harm. This source of standing need not be coextensive with the basis of the right at issue. ${ }^{286}$

Clearly much more can be said about how the Equal Protection theory put forward in this Article would reconfigure the case law governing treatment of non-citizens. This Article merely gives the reader a flavor of what that restructuring would produce and leaves for another day a more thorough analysis of how courts ought to treat distinctions based on noncitizen status.

\section{CONCLUSION}

In this Article I have argued that Equal Protection is best understood by focusing on the meaning of governmental action. Laws must classify. In order to achieve the most mundane and benign of purposes, the state must draw distinctions between people: tax laws, tuition rates at state universities, single-sex bathrooms, etc. The challenge of Equal Protection is to determine which of these distinctions violates the constitutional guarantee of Equal Protection and which different treatment does not. I argue that the right way to determine whether governmental action violates Equal Protection is by looking at the expressive dimension of that action.

The constitutional focus should be on the meaning or expressive character of governmental action. Those laws whose meaning conflicts with the proposition that we must matter equally to our government-what I have been calling the principle of equal concern-thereby violate Equal Protection. The challenge of this view is to demonstrate how a judge is to determine what a particular law or policy expresses. This Article explains that coherence principles will be of some aid in

286. See supra Part II.H for a more detailed discussion of standing issues. 
this difficult task. Given the diversity in people's beliefs, experiences, and values, however, there is likely to be significant differences in the way that different people and different judges understand the meaning of governmental actions. In my view, this is not a weakness of the theory but instead part of its strength.

The judge must interpret the meaning of laws or policies as best she can. As guidance in this endeavor, I offer the concept of an ideal conversation. The judge should try to ascertain what meaning would emerge from a conversation under fair conditions among real people with different views. Of course, in the real world, even the most thoughtful and conscientious judge can only approximate this ideal. In that sense, the meanings attributed to state actions will not be fully objective or social. Instead, they will be one person's or one court's assessment of the public meaning of the state action.

Before one condemns the theory on this ground, we ought to reconsider our aspirations for constitutional law, particularly in fields such as Equal Protection. Our country is made up of people with different values, beliefs, cultures, and experiences. Moreover, real people are going to apply constitutional principles. Our constitutional doctrines ought not strive to evade the limitations inherent in these constraints by offering a false sense of security or rectitude. Remember Black's comments about Wechsler's neutral principles. Instead, the goal of the doctrine is to channel our discussion to the right questions. If the meaning of governmental action is really what determines whether a law protects us equally, we must focus on that meaning.

Constitutional doctrine cannot be a panacea for the deep divisions among us. It can, however, provide a vehicle to understand each other better. Remember Moore's example of courtesy. In order to act courteously within a given culture, one must be seen as acting courteously. Similarly, in order for the government to respect each of us, the heart of the mandate of Equal Protection, the state must express that respect. This is why Equal Protection doctrine ought to focus on the expressive character of governmental actions. But how else can we come to understand the meaning of actions than by talking and listening to each other? Debates about the meaning of laws and policies, both inside and outside the courtroom, are important parts of this endeavor. 
[Vol. 85:1

Heinonline -- 85 Minn. L. Rev. 70 2000-2001 